Rakenteiden Mekaniikka (Journal of Structural Mechanics)

vol. 53, nro. 4, 2020, s. 356-389

http://rakenteidenmekaniikka.journal.fi/index

https://doi.org/10.23998/rm.87314

(C) 2020 kirjoittajat

Vapaasti saatavilla CC BY 4.0 -lisenssin mukaisesti

\title{
Laivojen pohjien likaantumisen vaikutus kulkuvastukseen Itämerellä: Chow-Liu-puulla täydennetyn Naiivi Bayes -mallin soveltaminen aluksen kulun analysointiin
}

Elias Altarriba

Tiivistelmä COMPLETE-hankkeen tavoitteena on ehkäistä haitallisten vieraslajien leviämistä Itämeren alueella. Leviämistä on tapahtunut merkittävästi laivojen painolastivesien mukana, mutta lajikkeita kulkeutuu merialueilta toisille myös vedenalaisiin runkorakenteisiin tarttuneina. Lisäksi biolikaantuminen kasvattaa aluksen kulkuvastusta ja sitä myötä polttoaineen kulutusta sekä hiilidioksidipäästöjä. Tällä hetkellä likaantumista rajoitetaan puhdistamalla pohjia säännöllisesti kesäkaudella. Puhdistusajankohdat valitaan laivakohtaisesti pääsääntöisesti kokemukseen perustuen. Myös puhdistuksilla usein koetaan olevan havaittavaa vaikutusta aluksen kulkuun veden halki, mutta mittauksiin perustuvia tietoja ei laivaväen käytössä ole. Nykyään laivojen järjestelmistä on mahdollista tallentaa kulkudataa enenevissä määrin. Luotettavien johtopäätösten tekeminen massadatasta vaatii kuitenkin asiaan soveltuvia työkaluja ja systeemin monien sekoittajien ominaisuuksien tuntemista. Tässä artikkelissa perehdytään Chow-Liu-puulla täydennetyn Naiivi Bayes -mallin hyödyntämiseen aluksen kulun analysointiin. Menetelmän etuina ovat laskennallinen tehokkuus ja luotettavuus kulkuvastuksen kausaatioiden tunnistamiseksi, vaikka käytettävissä olevaa dataa olisikin vain rajoitetusti.

Avainsanat: COMPLETE, laivaliikenne, pohjan likaantuminen, Itämeri, Naiivi Bayes

Vastaanotettu: 12.11.2019. Hyväksytty: 1.7.2020. Julkaistu verkossa: 4.11.2020.

\section{Johdanto}

Ympäristöongelmien hallinta on yksi tulevaisuuden keskeisiä haasteita. Hallitustenvälisen ilmastonmuutospaneeli IPCC:n julkaisemat erikoisraportit antavat yhteen vetävän kuvan niin ilmastonmuutoksen vaikutuksista yleisellä tasolla [1] kuin odotettavista muutoksista meriekosysteemeissä [2]. Itämeren ekosysteemiin vaikuttavat erityisesti meriveden lämpeneminen ja jäätalvien väheneminen. Itämeren lämpötila on noussut kuluneen sadan vuoden aikana keskimäärin $0,3{ }^{\circ} \mathrm{C}$ vuosikymmentä kohden [3], tosin Helsingin komissio 
HELCOM:n julkaiseman tutkimuksen mukaan vuoden 1990 jälkeen lämpötilan nousu on ollut jopa $0,59^{\circ} \mathrm{C}$ vuosikymmenessä [4]. Meriveden lämpötilan nousulla on laajoja vaikutuksia alueen eliöstöön, meren suolapitoisuuteen ja veden hapekkuuteen [5]. Ekosysteemeissä tapahtuvien muutosten kerrannaisvaikutusten ilmenemistä ja niiden keskinäistä vuorovaikutusta on haastavaa arvioida luotettavasti ennalta, mutta lämpimämpi meri ja jäättömät talvet tarjoavat monille merellisille kasvi- ja eliölajikkeille lähtökohtaisesti paremmat elinolosuhteet [6-8]. Yhtenä seurauksena Itämeren alueella liikennöivien laivojen pohjien biolikaantuminen voi siis merkittävästi nopeutua merellisten olosuhteiden muuttuessa.

Laivojen vedenalaisten runkorakenteiden likaantuminen biologisesta aineksesta kasvattaa alusten kulkuvastusta [9-12]. Mikäli pohjien annettaisiin likaantua suhteellisen vapaasti, olisi ilmiön vaikutus aluksen kulkuun hyvinkin dramaattinen polttoaineen kulutuksen noustessa useita kymmeniä prosentteja valitun kulkunopeuden pitämiseksi. Likaantumisesta aiheutuva kulkuvastuksen kasvaminen tuottaa suoria taloudellisia kustannuksia varustamoille puhdistusten, vedenalaisten rakenteiden pintakäsittelyn ja lisääntyneen polttoaineen kulutuksen muodossa, mutta myös tarpeetonta ilmastokuormitusta pakokaasupäästöjen lisääntyessä. Laivojen pohjiin kertyvä eliöstö voi muodostaa ekosysteemeille myös toisenlaisen uhan [13-15]: Haitallisten vieraslajien leviäminen merialueilta toisille on pahimmillaan romahduttanut ekosysteemejä ja ravintoketjuja, kun aggressiivinen tulokaslaji on syrjäyttänyt alueella aiemmin eläneitä lajikkeita. Painolastivedet ovat olleet merkittävä leviämisreitti merellisille vieraslajeille, minkä johdosta IMO:n kansainvälinen yleissopimus painolastivesien käsittelemisestä astui voimaan 7.9.2017 [16, 17]. Laivojen vedenalaisten runkorakenteiden mukana merialueilta toisille kulkeutuvat lajit ovat olleet huomattavasti vähemmän tutkittu asia. Erityisesti laivojen pohjia puhdistettaessa biologinen aines kuitenkin irtoaa ympäröivään meriveteen ollen useissa tapauksissa kuitenkin edelleen elinkelpoista [18, 19]. Osa satamista onkin tämän vuoksi rajoittanut pohjien puhdistamista tai velvoittanut puhdistajia keräämään pohjasta irtoavan aineksen talteen puhdistusten yhteydessä [20, 21].

COMPLETE-hanke on Interreg Baltic Sea Region-ohjelman puitteissa vuosina 20172020 toteutettava, EU-lippulaivastatuksen saanut kansainvälinen tutkimushanke [22]. Hanketta koordinoi Kotkassa sijaitseva Meriturvallisuuden ja -liikenteen tutkimuskeskus Merikotka ja hankkeeseen osallistuvat Helsingin yliopisto, Helsingin komissio HELCOM, Suomen ympäristökeskus, Pidä saaristo siistinä ry, Klaipedan yliopisto, Gdanskin yliopisto, Latvian Daugavpils-yliopisto, Tarton yliopisto, Chalmers-yliopisto ja Saksan liittotasavallan merenkulun ja hydrologian virasto BSH. Kaakkois-Suomen ammattikorkeakoulun merenkulun TKI:n rooli on toteuttaa yhdessä päästömittauslaboratorio KymiLabsin kanssa päästömittauksia ja kulkudatan tallentamista aluksilta niiden ollessa normaalissa kulussa. Tavoitteena on selvittää laivakohtaisesti pohjien likaantumisen mitattavissa olevaa vaikutusta aluksen kulkuun.

Alusten pohjien säännöllinen puhdistaminen on tunnistettu hyödylliseksi ja suhteellisen helposti toteutettavissa olevaksi menetelmäksi vähentää polttoaineen kulutusta [2325]. Säännöllisesti puhdistettavien alusten kansi- ja konepäällystöllä on tavallisesti kokemukseen perustuvaa tietoa pohjan puhdistuksen käytännön vaikutuksista aluksen kulkuun [26]. Mikäli aluksen pohjan puhdistusväli on muutamasta viikosta kuukauteen, ei eroavuus likaisen ja puhtaan pohjan muodostaman kulkuvastuksen välillä ole vielä suuren 
suuri. Puhutaan suuruusluokaltaan ehkä noin puolen solmun nopeuserosta samalla työntöteholla noin 20 solmun matkavauhdissa. Kuitenkin erityisesti pidemmällä aikavälillä säästöt polttoaineen kulutuksessa ovat huomattavat ja kattavat pohjan puhdistamisesta aiheutuvat kustannukset tehokkaasti.

COMPLETE-hankkeessa mukana olevien varustamojen (Finnlines, Viking Line, Tallink Silja) alusten pohjia puhdistetaan kesäkaudella säännöllisesti. Puhdistusvälit ovat varustamo- ja laivakohtaisia, mutta tavallisesti puhdistuksia tehdään noin 6-8 kappaletta kesäkauden aikana. Osalla laivoista puhdistus suoritetaan keskikesällä kahden viikon välein siinä missä toisilla aluksilla puhdistusväli on neljä viikkoa. Tavallisesti kesäkauden ensimmäinen puhdistus suoritetaan toukokuussa ja säännölliset puhdistukset päättyvät yleensä viimeistään lokakuussa. Puhdistus toteutetaan sukeltajien toimesta aluksen ollessa satamassa. Aluksen koko pohjaa ei tuolloin puhdisteta, vaan toimenpiteet kohdistuvat aluksen vesirajan alapuolisiin kylkiin ulottuen tavallisesti noin 2-3 metrin syvyyteen, tarpeen vaatiessa syvemmällekin.

Vedenalaisiin runkorakenteisiin kertyvä kasvusto lisääntyy nopeimmin lämpimissä pintavesissä, missä auringonvaloa on tarjolla merkittävästi. Asia korostuu entisestään, mikäli tarkastellaan pitkiä aikoja satamassa viettäviä aluksia [9]. Kuitenkin myös säännöllisessä linjaliikenteessä olevien alusten kylkiin kertyvässä kasvustossa on nähtävissä muutoksia jopa sen suhteen, kumpi kylki aluksesta asettuu tavallisesti auringon suuntaan satamajaksojen aikana. Tämä näkyy myös keulabulbiin kerääntyvän kasvuston määrässä, erityisesti aluksen keulan asemoituessa laituripaikallaan etelän suuntaan auringon päästessä paistamaan bulbiin esteettä.

Epoksipohjaisiin hard coat -tyyppisiin pintakäsittelyaineisiin kasvustoa kertyy Itämeren meriolosuhteissa kesäkausilla jo muutamassa viikossa. Kesäkauden suursäätilalla ja meren lämpötilalla on luonnollisesti vaikutusta kasvuston kasvunopeuteen. Kasvuston kehittyminen nopeutuu merkittävästi pintaveden lämpötilan noustessa yli $20^{\circ} \mathrm{C}$ asteen, mutta $10-20{ }^{\circ} \mathrm{C}$ lämpötilassakin lisääntyminen on jo huomattavaa. Kokemukseen [27] perustuen alkukesästä, jolloin meriveden lämpötila on tavallisesti $10-15^{\circ} \mathrm{C}$, kuukauden tarkastelujaksolla kylkiin kertyy tavallisesti 0-20 mm pituista levää ulottuen yleensä vähintään kahden metrin syvyyteen asti. Mikäli tarkastelujakson päivät ovat olleet pääsääntöisesti aurinkoisia ja vedessä on näin ollut paljon valoa, voivat leväkasvustot olla kiinnittyneenä aluksen kylkiin myös syvemmälläkin, jopa 3-4 metrin syvyydessäkin. Loppukesästä meriveden lämpötilan ollessa tavallisesti korkeampi, kasvavat myös levät kuukauden aikana nopeammin. Tuolloin on tavallista, että leväkasvustot voivat olla pituudeltaan 30-50 mm, eivätkä jopa $100 \mathrm{~mm}$ pituiset levät ole tavattomia. Myös kasvusto ulottuu selkeästi syvemmälle, tavallisesti 4-5 metriin asti. Puhdistettaessa pohjaa noin kuukauden kasvanut levä on vielä suhteellisen helposti harjattavissa irti siinä missä kaksikuukautinen levä on takertunut maalipintaan jo huomattavasti vahvemmin, ollen muutoinkin sitkeämpää ja väriltään tummempaa. Pituudeltaan pidemmän leväkasvuston lisäksi pohjaan kertyy myös limamaista kasvustoa. Maalipinnan laadulla ja pintakäsittelyaineen iällä on myös havaittavaa vaikutusta levien ja limojen kykyyn tarttua vedenalaisiin rakenteisiin.

Talvikaudella pohjia ei puhdisteta. Merellä jäissä kulkeminen irrottaa kasvustoa tehokkaasti ja jäiden vaikutus pintakäsittelyyn on pääsääntöisesti hiova. Lisäksi jääolosuhteet satama-altaissa ovat sukeltajille haastavat. Vaikka talvi olisikin lämmin ja Itämeri 
pääasiassa sula, kehittyy erityisesti Suomen rannikoille satamat mukaan luettuina tavallisesti kuitenkin jäätä. Aluksen saapuessa satamaan jäät puristuvat laiturin ja aluksen väliin, jolloin jäälauttoja yleensä ajautuu myös aluksen alle tasapohjaa vasten. Näissä olosuhteissa pohjan puhdistaminen sukeltajien toimesta on käytännössä hyvin haastavaa ja vaarallista, usein suorastaan mahdotonta. Meriveden keskimääräisen lämpötilan nouseminen ilmaston lämpenemisen seurauksena ja jäätalvien väheneminen tuottaa ylimääräisen haasteen myös pohjien puhdistamiselle: Puhdistustarve todennäköisesti kasvaa meren ollessa pääasiassa jäistä vapaa, mutta näiden operaatioiden toteuttaminen jäisissä satamissa ei olekaan välttämättä mahdollista. Tämä korostuu erityisesti sellaisessa säännöllisessä linjaliikenteessä, missä pohjan puhdistaminen on tehtävä kotimaisessa satamassa ulkomaisen, kenties sulana pysyvän sataman asettamien puhdistusrajoitusten vuoksi.

Päätökset pohjien puhdistusaikatauluista ja -tarpeista tehdään varustamoissa pääsääntöisesti kokemukseen perustuen [26, 27]. Saatavilla oleva ja periaatteessa varustamoiden kannalta sovellettavaksi kelpaava tutkimustieto pohjien likaantumisesta painottaa usein ilmiön teoreettista viitekehystä, eri merialueilla pohjiin kertyvien kasvustojen ja eliöiden lajikkeita tai pohjan likaantumisen vaikutusta alusten polttoaineen kulutukseen yleisellä tasolla [28-30]. Erityisesti jälkimmäisissä tutkimuksissa korostuvat usein erittäin likaantuneet pohjat, jolloin likaantumisen vaikutus polttoaineen kulutukseen voi olla hyvinkin merkittävä. Lisäksi joskus näitä tietoja esitetään myös kaupallisia tarkoituksia ajatellen.

Varustamojen mahdollisuudet tallentaa kulkudataa aluksiltaan kehittyvät jatkuvasti. Aiemmin laivojen analogiset järjestelmät mahdollistivat kulkudatan tallennuksen ainoastaan käsityönä, mikä yleensä toteutettiin hyvin suurpiirteisesti aluksen kulun, lastauksen, kirjanpidon, bunkrausten ja huoltojen osalta. Järjestelmien digitalisoituminen käynnistyi asteittain 1980-luvun lopulla. Ensimmäiset järjestelmät olivat lähinnä ohjaus- ja valvontajärjestelmiä, missä tietojen tallentaminen tapahtui manuaalisesti printterillä. Sittemmin datan tallentaminen mahdollistui ensin käyttäjän pyynnöstä ja myöhemmin automaattisesti, mitä VDR-järjestelmätkin hyödyntävät. Nykyään uudemmissa aluksissa aluksen kulkudata operointiolosuhteineen tavallisesti tallentuu automaattisesti varustamon tai laivaväen käyttöön. Myös vanhojen laivojen järjestelmiä päivitetään, jolloin tallenteita voidaan saada myös vanhemmilta aluksilta.

Numeerista dataa alusten kulusta ja kulkuolosuhteista on siis laivaväen, varustamojen, viranomaisten ja muiden tahojen käytössä enenevissä määrin. Monilta alustyypeiltä on tallennettavissa keskeiset aluksen kulkua indikoivat muuttujat. Näitä ovat muun muassa polttoaineen kulutus, akselitehot, potkureiden nousut ja pyörimisnopeudet, nopeustieto pohjan suhteen, aluksen trimmi ja lastaus sekä aluksen oman säähavaintoaseman tallenteet. Lisäksi Itämeren rannikkovaltioiden ilmatieteen laitoksilla on numeerisessa muodossa pitkäaikaista havaintodataa niin alueiden sääolosuhteista kuin meriveden lämpötilasta ja suolapitoisuudestakin. AIS-järjestelmä tallentaa aluksen sijainnin, nopeuden, kurssin ja monia muita järjestelmään syötettyjä muuttujia, kuten aluksen ilmoitetun staattisen syväyksen. Lisäksi varustamoilla on jo kirjanpitovelvoitteen johdosta paljon olemassa olevaa tietoa alustensa kustannusrakenteesta: Laiva on monessa mielessä kuin tehdas.

Tämä datakokonaisuus muodostaa tyypillisen massadataongelman [31, 32]: Data sisältää aluksen kulun analysoinnin kannalta valtavasti tietoa, mutta sen hyödyntäminen onnistuu vain harvoin suoraviivaisesti: Data on kerätty eri lähteistä, tallennusmuodot 
poikkeavat toisistaan, tallenneintervallit voivat olla eripituisia, muuttujien toleranssit vaihtelevat ja tuntemattomia tai vaikeasti havainnoitavia tekijöitä on systeemissä useita. Osittain tämä juontuu siitä, että dataa on tuotettu monien tahojen toimesta pitkällä aikavälillä ilman tietoa sen lopullisesta käyttötarkoituksesta. Tällä hetkellä tallentunut data on usein varsin puutteellisesti hyödynnettyä, tosin tulevaisuudessa asia voi muuttua erityisesti, mikäli alusten kulkudataa tallentavat ohjelmistot kehittyvät siihen suuntaan, että varustamot pystyvät enenevissä määrin hyötymään datasta kaupallisesti suhteellisen pienellä analysointiin käytettävällä työpanoksella.

Pohjan likaantuminen on yksi aluksen kulkuvastukseen vaikuttavista muuttujista. Tutkimusongelmaa voidaan lähestyä esimerkiksi CFD-virtausmalleilla [33, 34] tai koealtaissa suoritettavilla ITTC-laivamallikokeilla $[35,36]$. Tässä tutkimuksessa sovelletaan havainnoivaa, semiempiiristä tutkimusmenetelmää, missä analysoidaan todellisissa ympäristöissään liikkuvilta aluksilta tallennettua kulkudataa. Valitun menetelmän ongelmana ovat systeemin lukuisat sekoittajat ja muut häiriötekijät, joita todellisessa ympäristössä aina on. Toisaalta menetelmän selkeänä etuna on havainnoinnin tekeminen nimenomaan aidossa ympäristössä kaikkine muuttujineen ja mahdollisuus tehdä johtopäätöksiä laivakohtaisesti: Käytännössä varustamot kuitenkin joutuvat tekemään päätökset esimerkiksi pohjamaalivalinnoista tai puhdistusväleistä kuitenkin laivakohtaisesti; mikä perustelee laivakohtaisen, havainnoivan tutkimusmenetelmän valintaa.

Tässä artikkelissa perehdytään bayesiläisessä tilastotieteessä sovellettavien kausaatioverkkojen [37-39] soveltuvuuteen aluksen kulun analysointiin. Aluksen dynaamiseen kulkuvastukseen vaikuttavat monet muuttujat, kuten esimerkiksi valittu ajonopeus, vallitseva säätila aalto-olosuhteineen, alueella vaikuttavat virtaukset, aluksen lastaus ja trimmi, sekä toteutetut ohjailutoimenpiteet. Näiden lisäksi kulkuvastukseen vaikuttavat myös aluksen pohjan puhtaus ja pintakäsittelyn eheys [40-42]. Osa muuttujista, kuten lastaus ja trimmi, ovat matkakohtaisia muuttujia. Säätila voi vaihtua alueellisesti varsin nopeastikin ja Itämerellä pääasiassa säätilan vaihteluista johtuvat virtaukset seuraavat sään muutoksia viipeellä. Matalassa vedessä operoitaessa kulkuvastusta lisäävän pohjaefektin vaikutus minimoituu valitulla alustyypillä meren syvyyden ylittäessä $40 \ldots 50$ metriä. Avomerilegeillä aktiivisia ohjailutoimia tehdään pääasiassa sään aiheuttaman sorron korjaamiseen. Silläkin on havaittavissa olevaa vaikutusta, annetaanko sortoennakko kurssimuutoksena, peräsinohjauksella vai tuotetaanko toisella potkurilla suurempi työntö sortovaikutuksen korjaamiseksi.

Pohjan likaantumisen seurauksena kulkuvastuksen voidaan olettaa kasvavan suhteellisen kumulatiivisesti, ainakin tarkasteltaessa noin kuukausittaista ajanjaksoa, mikä on tutkittavan aluksen pohjan puhdistusväli kesäkautena. Tämä tekee likaantumisesta selkeästi erityyppisen muuttujan verrattuna moniin muihin edellä mainittuihin muuttujiin, mikä helpottaa likaantumisefektin havainnointia. Kyseessä on tyypillinen kausaalinen ongelma, missä kasvuston aiheuttama kulkuvastuksen lisäys näkyy aluksen vaatimassa tehontarpeessa ja näin myös polttoaineen kulutuksessa. Koska pohjan likaantumisasteesta ei kuitenkaan ole käytettävissä malliin syötettävissä olevaa numeerista dataa, testataan tässä artikkelissa Chow-Liu-puulla täydennettyä Naiivi Bayes -mallia alukselta tallentuneiden, paremmin tunnettujen muuttujien analysointiin. Samalla saadaan tietoa näiden muuttujien vaikutuksesta aluksen kulkuun, mitä tarvitaan havainnoitaessa pohjan likaantumisen vaikutusta artikkelisarjan seuraavassa osassa. 


\section{Kausaatiomalli aluksen kulusta}

Laivan kulkua simuloiva, merkittävimmät muuttujat sisältävä kausaatiosysteemi voidaan esittää kuvassa 1 esitetyllä kausaalimallilla. Systeemistä löytyvät propulsiojärjestelmän keskeiset muuttujat, laivan lastauksen vaikutus, valittu nopeus niin ilman kuin vedenkin suhteen sekä säätilan moninainen vaikutus aluksen kulkuun. Pohjan pintakäsittelymenetelmä ja sen likaantuminen on myös sisällytetty esitettyyn kausaatiomalliin.

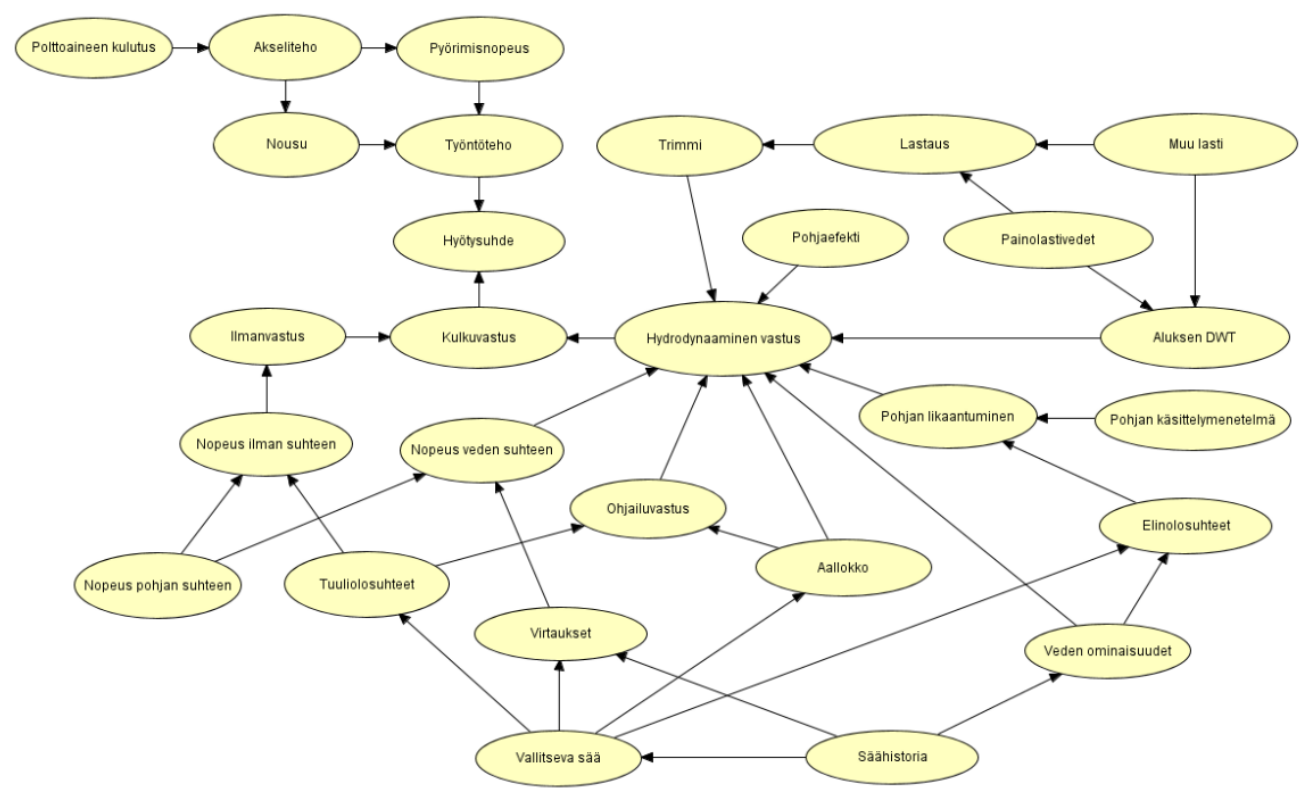

Kuva 1. Aluksen kulkua simuloiva kausaatiosysteemi

Usein aluksen kulkua tarkasteltaessa propulsioon liittyvien muuttujien data on helpoimmin ja luotettavimmin saatavissa. Polttoaineen kulutuksen osalta varustamoilla on vuodesta 2019 ollut raportointivelvollisuus, tosin käytännössä tämä voi tarkoittaa hyvin suurpiirteistä, esimerkiksi matkakohtaista kulutuksen tarkastelua. Tekniseltä iältään uudemmat järjestelmät kuitenkin tallentavat tai ainakin tarjoavat mahdollisuuden tallentaa kulutustietoja ajan funktiona. Parhaimmillaan tallentuva data huomioi polttoaineen laadussa tai lämpötilassa mahdollisesti ilmenevät eroavuudet. Yksinkertaisimmillaan kyseessä on ainoastaan virtausdata moottoreille menevästä polttoainevirrasta. Ajettaessa moottoreita normaalilla käyttö- ja kuormitusalueellaan polttoaineen kulutus indikoi suhteellisen ennustettavasti akselitehoa. Potkureiden tuottaman työntövoiman suuruuteen vaikuttavat vakionopeudella ajettaessa pääasiassa pyörimisnopeus ja nousukulmat.

Lastauksella on merkittävä vaikutus aluksen kulkuvastukseen. Lastaus on kuvassa 1 jaettu muuhun lastiin ja painolastivesiin. Lastauksen seurauksena DWT kasvaa, jolloin aluksen liikkuminen vaatii enemmän energiaa. Märkäpinta-alan kasvaessa hydrodynaaminen vastus lisääntyy selkeästi enemmän verrattuna pienentyvään ilmanvastukseen. Lisäksi lastauksen sijoittelu vaikuttaa aluksen trimmiin, millä on monimutkainen vaikutus aluksen kulkuvastukseen. Trimmi vaikuttaa aluksen hydrodynamiikkaan muun muassa bulbin tehokkuuden kautta [43]. Erityisesti, mikäli staattisen satamatrimmin ja DWT:n 
muutokset ovat suuria, on niillä vaikutusta myös dynaamisen trimmin muutoksiin työntötehon funktiona.

Kuvassa 1 pohjan likaantuminen on esitetty erillisenä kausaalisena ketjuna. Likaantuminen kasvattaa aluksen hydrodynaamista vastusta ja sen kehittymiseen vaikuttavat pohjan pintakäsittelymenetelmä ja biologisen aineksen muut elinolosuhteet aluksen runkorakenteissa [44]. Tarpeen vaatiessa tarkastelua voidaan syventää monellakin tavalla: Elinolosuhteisiin vaikuttavat muun muassa veden lämpötila, aurinkoisuus, alueella elävät lajikkeet, aluksen satamassa viettämä aika, veden ravinteikkuus ja suolapitoisuus, sekä vuodenaika ja talvikauden jäätilanne. Pohjan pintakäsittelymenetelmä itse asiassa vaikuttaa suoraan kasvuston elinolosuhteisiin runkorakenteissa, mutta selkeästi varustamon valittavissa olevana asiana se on perusteltua esittää erillisenä muuttujana [9, 45]. Itämerellä tyypilliset hard coat -epoksimaalit ovat huono kasvualusta eliöille, mutta valitulla pintakäsittelymenetelmällä voi olla myös varsinaisia anti-fouling-ominaisuuksia, jolloin eliöiden selviytymiseen vaikutetaan kemiallisesti. Foul-release-tyyppiset maalit kiillottuvat suunnitellusti aluksen liikkuessa veden halki, jolloin pintaan kertynyt kasvusto irtoaa operoinnin aikana. Kuparipohjaiset myrkkymaalit ovat tehokkaimpia kasvuston torjujia, mutta niistä meriympäristöön irtoavien myrkkyjen johdosta niiden käyttö on vähentynyt merkittävästi.

Nopeus on esitetyssä kausaatioverkossa eriytetty omaksi kokonaisuudekseen, sillä nopeudella on merkittävä vaikutus kulkuvastukseen puhuttaessa aluksen nopeudesta niin ilman kuin vedenkin suhteen. Näihin molempiin muuttujiin liittyvät läheisesti myös vallitsevat sääolosuhteet ja kuvan 1 kausaatioverkosta voikin havaita sään ollessa systeemin merkittävin sekoittaja. Lisäksi sään vaikutusten voidaan katsoa ilmenevän hetkellisesti (aluksen nopeus ilman suhteen), lyhyellä (aaltovastus, pintavirtaukset) tai pitkällä aikavälillä (meren lämpötila, suolapulssit, jäätilanne, pohjan likaantumisnopeus). On selvää, että kuvassa 1 esitetyn kausaatiomallin tehokas ja luotettava soveltaminen on haasteellista johtuen jo pelkästään datan määrästä ja eri lähteistä kootun datan laadun vaihtelusta. Erityisesti vallitsevista sääolosuhteista voidaan usein saada ainoastaan indiisidataa, vaikka sään vaihteluiden vaikutus aluksen kulkuun on monissa tilanteissa välitön.

\section{Chow-Liu-puulla täydennetty Naiivi Bayes -malli}

Naiivi Bayes -menetelmä on Bayes-tilastotieteen luokitintyökalu. Kyseessä on yksinkertainen, laskennallisesti tehokas ja varsin luotettavaksi osoittautunut lähestymistapa monimutkaisten ongelmien analysointiin [46, 47]. Menetelmän erityispiirteenä on olettama analysoitavien systeemien piirremuuttujien keskinäisestä riippumattomuudesta edellyttäen, että systeemin luokkamuuttujan saamat arvot tunnetaan. Tämä olettama reaalimaailmassa pitää paikkaansa vain harvoin, mutta tästä huolimatta Naiivi Bayes -malli tarjoaa usein yllättävän tarkkoja ja soveltamiskelpoisia ratkaisuja myös tilanteissa, missä muuttujien todelliset riippuvuussuhteet ovat vahvoja [39, 48, 49]. Tämän vuoksi menetelmää on hyödynnetty muun muassa lääketieteen tutkimuksessa, sairauksien diagnosoinnissa, tekstianalyyseissä ja roskapostisuodattimissa [38]. Myös 1990-luvun lopulla MS Office ohjelmistojen käyttäjiä usein ärsyttäneen "agenttiapulaisen" toiminta perustui Naiivi Bayes -malliin. 
Todennäköisyyslaskennan perusaksioomien mukaan $x$ :n todennäköisyys ehdolla $y$ lausutaan yhtälöllä

$$
p(x \mid y)=\frac{p(x \cap y)}{p(y)} .
$$

Vastaavasti asiaa voidaan tarkastella myös ehdollisen todennäköisyyden yhtälöllä

$$
p(y \mid x)=\frac{p(x \cap y)}{p(x)} .
$$

Useissa tapauksissa nämä yhtälöt johtavat kuitenkin erilaiseen lopputulokseen. Bayesin teoreema [50] määrittää suhteen näiden kahden tapahtuman välillä. Tämä voidaan lausua yhtälöllä

$$
p(y \mid x)=\frac{p(x \mid y) p(y)}{p(x)}
$$

missä $p(x)$ on $x$ :n ja $p(y) y: n$ priori-todennäköisyys, $p(x \mid y)$ posterioritodennäköisyys ja $p(y \mid x) y: n$ todennäköisyys ehdolla $x$. Bayesin teoreeman mukaan priori-todennäköisyys $p(x)$ voidaan olettaa vakioksi, minkä vuoksi oppimisjoukon kokonaisuskottavuutta määrittävän posterioritodennäköisyyden $p(x \mid y)$ ja mallistruktuurin priori-todennäköisyyden $p(x)$ tuloa voidaan käyttää bayesiläisenä oppimiskriteerinä [39]. Bayesin teoreemassa esitetty kokonaisuskottavuus on johdettu tilastotieteessä paljon sovelletusta uskottavuustermistä $p_{d}=p(y \mid x, \theta)$ integroimalla parametrien prioritodennäköisyyksillä $\theta$ painotettu uskottavuustermi yli kaikkien mallistruktuuria $x$ vastaavien mallien.

Naiivi Bayes -luokittelumenetelmä soveltuu hyvin tiedonlouhintaan massadatasta [47]. Louhinnan luotettavuuden osalta datan esikäsittelyllä on prosessissa keskeinen asema sisältäen tässä tapauksessa muun muassa vallinneiden sääolosuhteiden huomioimisen jo esikäsittelyvaiheessa. Ennen pohjan likaantumisen vaikutuksen havainnointia on kuitenkin oleellista tuntea muiden keskeisten aluksen kulkuun vaikuttavien muuttujien luonteenpiirteitä, jotta virheellisiä päätelmiä ei tehtäisi tai tuloksiin tuotettaisi merkittävää rakenteellista vinoumaa johtuen puutteellisesta datan esikäsittelystä.

Naiivi Bayes -menetelmässä muuttujajoukosta valitun luokkamuuttujan diskreetin jakauman suhteen lasketaan muiden muuttujien arvokombinaatiot. Tämän toteuttamiseksi määritetään systeemin yhteistodennäköisyysjakauma yhtälöllä

$$
p\left(x_{1}, \ldots, x_{n} \mid C\right) p(C)=p(C) \prod_{i=1}^{n} p\left(x_{i} \mid C\right),
$$

missä $C$ on luokkamuuttuja ja muuttujat $1 \ldots n$ ovat systeemin muita piirremuuttujia, jotka siis oletetaan Naiivi Bayes -menetelmässä keskenään riippumattomiksi. Sijoittamalla yhteistodennäköisyysjakauma Bayesin teoreemaan, saadaan Naiivi Bayes -menetelmää määrittävä peruskaava 


$$
p\left(C \mid x_{1} \ldots x_{n}\right)=\frac{p(C) \prod_{i=1}^{n} p\left(x_{i} \mid C\right)}{\prod_{i=1}^{n} p\left(x_{i}\right)} .
$$

Naiivi Bayes -menetelmän laskennallinen tehokkuus perustuu riippumattomuusoletuksesta seuraavaan verkkostruktuuriin, mikä yksinkertaisimmillaan sisältää vain kaksi muuttujakerrosta. Toisaalta on syytä huomioida, että tämän menetelmän antama jakauma luokkamuuttujalle ei välttämättä ole kovinkaan tarkka. Tämän vuoksi menetelmää harvemmin käytetään esimerkiksi riskianalyysiin, mutta toisaalta ilmenevän vinouman johdonmukaisuuden seurauksena menetelmän käytettävyys on silti useissa tapauksissa hyvä. Naiivi Bayes -verkkorakennetta on visualisoitu kuvassa 2, missä $C$ on systeemin luokkamuuttuja ja tässä esimerkissä muut neljä muuttujaa $x 1 \ldots x 4$ ovat siis teoreettisesti toisistaan riippumattomia.

Edellä kuvatun kaksiportaisen mallin sovellettavuudella on kuitenkin rajoitteensa. Sovellusmahdollisuuksien laajentamiseksi menetelmää käytetään usein Chow'n-Liun uskomusverkkopuulla [51] täydennetyssä muodossa (Tree-Augmented Naïve Bayes, TAN). Tällä menetelmällä on mahdollista havaita myös muiden muuttujien välisiä kytköksiä riippumattomuusoletuksesta huolimatta [52]. Chow'n-Liun menetelmässä painokertoimia käyttämällä saavutetaan suurimpaan todennäköisyyteen perustuva, visualisoitu puurakenne. Kuvassa 3 on esimerkki puurakenteella täydennetystä Naiivi Bayes -verkosta.

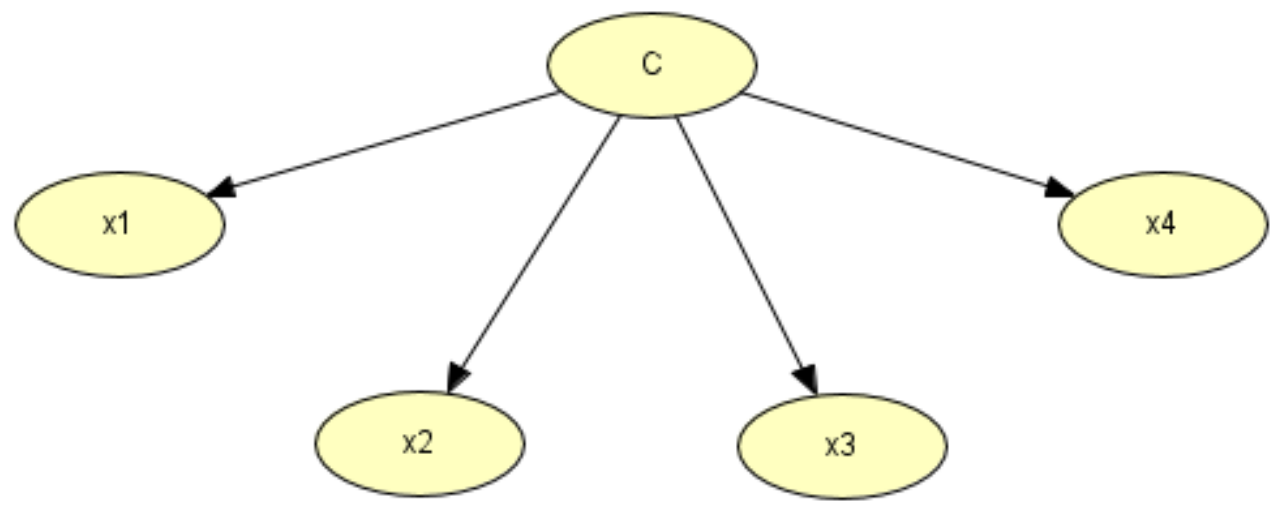

Kuva 2. Esimerkki Naiivi Bayes-verkosta

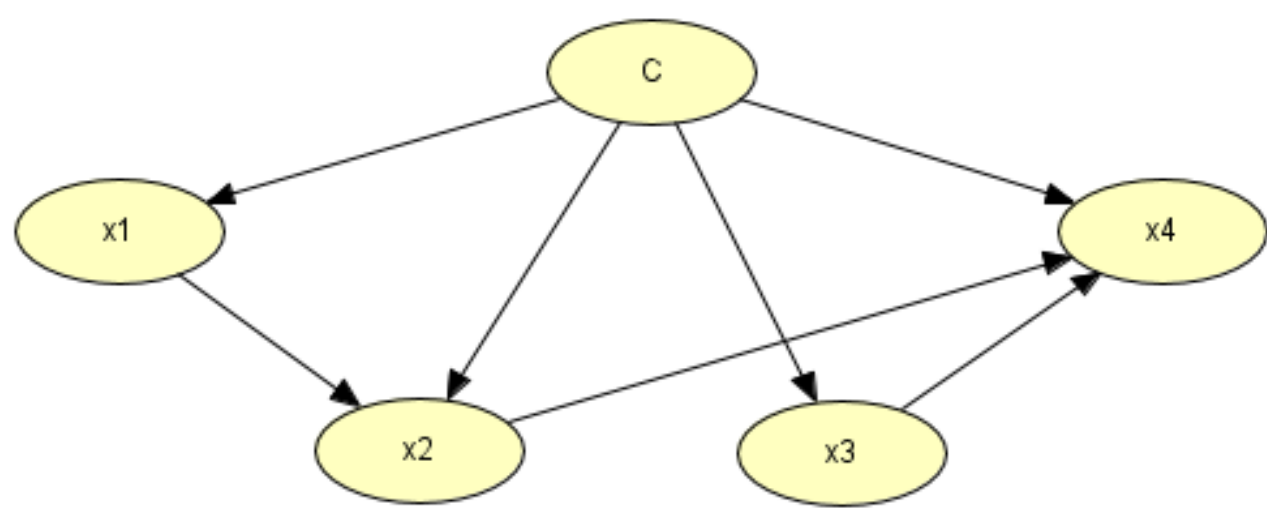

Kuva 3. Esimerkki Naiivi Bayes -verkosta Chow-Liu-puurakenteella täydennettynä 
Puurakenteella täydennetyssä Naiivi Bayes -mallissa piirremuuttujilla on systeemin luokkamuuttujan lisäksi usein myös muita vanhempia: Esimerkiksi kuvassa 3 muuttujan $x 2$ vanhempia ovat piirremuuttuja $x 1$ ja luokkamuuttuja $C$. Vastaavasti $x 2$ toimii vanhemman asemassa piirremuuttujalle $x 4$. Verkossa voisi olla myös lisää muuttujia esimerkiksi siten, että $x 4$ toimisi ainoana vanhempana uudelle muuttujalle $x 5$. Chow'n-Liun puurakenne luodaan soveltamalla piirrevektoriparien $X$ ja $Y$ yhteistä informaatiota kuvaavaa yhtälöä [51].

$$
I_{p}(X ; Y)=\sum_{x, y} p(x, y) \log \left(\frac{p(x, y)}{p(x) p(y)}\right)
$$

Piirrevektoreiden yhteinen informaatio lausutaan luokkamuuttujan $C$ ehdolla

$$
I_{p}(X ; Y \mid C)=\sum_{x, y, c} p(x, y, c) \log \left(\frac{p(x, y \mid c)}{p(x \mid c) p(y \mid c)}\right)
$$

jokaiselle piirrevektoriparille $X_{i}$ ja $Y_{j}($ kun $i \neq j$ ). Tätä käytetään painokertoimena muodostetussa yhteisverkossa, missä kaikkien piirremuuttujien oletetaan olevan yhteydessä toisiinsa. Tämän jälkeen valitaan yhteisverkosta painokertoimiltaan vahvimmat vuorovaikutukset, jotka lopuksi suunnataan valitusta luokkamuuttujasta poispäin [51]. Muodostuneen approksimaation laatukriteerinä käytetään Kullback-Leibler-etäisyyttä aineiston jakauman ja Chow-Liu-puun määrittämän jakauman välillä. Näin saadaan muodostettua TAN-luokittimelle yhtälö

$$
p\left(C \mid x_{1}, \ldots, x_{n}\right)=p(C)\left(p\left(x_{\text {root }} \mid C\right) \prod_{i} p\left(x_{i} \mid C, x_{\text {parent }}\right)\right. \text {. }
$$

Kuten kuvassa 1 visualisoitu kausaatiosysteemi osoittaa, vaatii aluksen kulkua simuloiva malli merkittävästi datasyötteitä, vaikka esitetty malli onkin tällaisenaankin vielä sangen yksinkertainen. Toisaalta Naiivi Bayes -mallin soveltuvuus moniin eri tutkimusongelmiin aiemmin mainitusta riippumattomuusolettamuksesta huolimatta perustuu piirteiden tosiasiassa sisältämän informaation määrään, joka monissa tapauksissa voi olla hyvinkin merkittävä. Tämän tutkimuksen tavoitteita ajatellen näistä informaatiokytköksistä on sekä hyötyä että haittaa: Toisaalta voidaan hyödyntää laskennallisesti tehokasta Naiivi Bayes -menetelmää, toisaalta esimerkiksi sääolosuhteet toimivat systeemin sekoittajana peittäen pahimmillaan pohjan likaantumisesta aiheutuvan kumulatiivisen muutoksen kulkuvastukseen. Sekoittajien vaikutusta analyysiin voidaan vähentää datan esikäsittelyvaiheessa karsimalla pois datasta sellaiset ajanjaksot, jolloin rannikkosääasemien tallenteiden perusteella sää on ollut tuulinen (selkeästi yli $5 \mathrm{~m} / \mathrm{s}$ ), virtaukset merkitseviä (yli 10 $\mathrm{cm} / \mathrm{s}$ ), aluksen trimmi tavanomaisesta poikkeava (normaali trimmi $-0,4 \ldots-0,6 \mathrm{~m}$ ) ja valitsemalla tarkasteluun ainoastaan sellaiset matkat, jolloin aluksen DWT on ollut suuruusluokaltaan samansuuruinen. Tämänkaltaisessa havainnoivassa tutkimuksessa on kuitenkin selvää, että kovin tarkkoja rajoja näille muuttujille ei voida asettaa. Selvää on myös, että esimerkiksi tuuliolosuhteet merellä voivat poiketa rannikkoaseman tarjoamasta tuu- 
lidatasta, eikä meren yllä vallitsevaa tuuliprofiilia voi muutenkaan yhdellä lukuarvomuuttujalla esittää. Näiden muuttujien olemassaolosta ja vaihteluista voidaan kuitenkin saada tietoa aluksen laskennallisen hyötysuhteen avulla.

\section{Laivan kulkuvastuksen laskenta}

Laskennallinen hyötysuhde on teoreettinen arvo. Kyseessä ei oikeastaan ole hyötysuhde sen varsinaisessa merkityksessään vaan pikemminkin indikaattori, jonka avulla voidaan havainnoida aluksen ympäristön olosuhteissa mahdollisesti ilmeneviä muutoksia, jotka eivät ole suoraan tallentuneet mihinkään datajoukkoon. Ajettaessa vakionopeudella potkureiden tuottaman työntötehon ja kulkuvastuksen suhteen tulisi pysyä suunnilleen samana edellyttäen, että kulkuympäristön olosuhteissa ei tapahdu merkittäviä muutoksia. Menetelmä on erityisen käyttökelpoinen tällaisessa tilanteessa, missä käytettävissä on tehodata akseleiden torsiometreiltä aluksen ajaessa jatkuvasti samaa reittiä, suunnilleen samalla nopeudella, eikä lastauksessakaan yleensä tapahdu radikaaleja muutoksia matkojen välillä. Menetelmän avulla voidaan osaltaan varmistua siitä, että esimerkiksi eri merialueilla vallitsevat sää- tai virtausolosuhteet ovat keskenään vertailukelpoiset. Laskennallisen hyötysuhteen määrittämiseen liittyviä menetelmiä ja niiden taustoja on käsitelty tarkemmin artikkelissa [53]. Tässä julkaisussa esitetään ainoastaan ROPAX-aluksen kulkuvastuksen laskentaan soveltuva menetelmä. Aluksen kulkuvastus [42] muodostuu ilmanvastuksesta $\left(F_{\text {ilma }}\right)$ ja hydrodynaamisesta vastuksesta $\left(F_{\text {hydr }}\right)$

$$
R_{T}=F_{h y d r}+F_{\text {ilma }},
$$

sisältäen hydrodynaamisen kulkuvastusyhtälön

$$
F_{\text {hydr }}=\frac{1}{2} \rho_{\text {vesi }} S C_{T} v_{\text {nop }}^{2},
$$

missä $C_{T}$ on hydrodynaamisen vastuksen kerroin. Kerroin sisältää aluksen kulkuvastuksen pääkomponentit, eli viskoottisen vastuksen ja aaltovastuksen. Lisäksi yhtälössä on kertoimet pinnankarheuden ja bulbin vaikutukselle skaalauskertoimineen, sekä ohjailuvastukselle:

$$
C_{T}=C_{f}+C_{r}+\Delta C_{f}+\Delta C_{a}+\Delta C_{b l}+\Delta C_{l} .
$$

Aluksen viskoottinen vastus lasketaan Grigsonin $[54,55]$ yhtälöllä 


$$
\begin{gathered}
10^{3} C_{f(\text { Grigson })}=\left(1,032+0,02816\left(\lg R_{n}-8\right)\right. \\
\left.-0,006273\left(\lg R_{n}-8\right)^{2}\right) \frac{0,075}{\left(\lg R_{n}-2\right)^{2}}
\end{gathered}
$$

$$
\text { kun } 10^{8}<R_{n}<4 * 10^{9},
$$

ja aluksen Reynoldsin luku lasketaan yhtälöllä

$$
R_{n}=\frac{v_{n o p} L_{w l}}{v_{k i n}} .
$$

Aaltovastuksen määrittämiseen käytetään Harvaldin-Taylorin yhtälöä [56, 57]

$$
\begin{aligned}
& 10^{3} C_{r}=1,2 * 10^{-3}\left(10 F_{n}-0,8\right)^{4}\left(10 C_{p}-3,3\right)^{2}\left(10^{3} C_{v}+4\right)+0,05 * 10^{3} C_{v}+0,2+ \\
& 0,17\left(\frac{B}{T}-2,5\right),
\end{aligned}
$$

missä Frouden luku $\left(F_{n}\right)$, prismaattinen täyteläisyys $\left(C_{p}\right)$, uppouman hoikkuusluku $\left(C_{v}\right)$ ja näiden määrittelyyn vaadittavat uppouman $\left(C_{b}\right)$ ja keskilaivankaaren täyteläisyysluvut $\left(C_{m}\right)$ määritetään yhtälöillä

$$
\begin{gathered}
F_{n}=\frac{v_{n o p}}{\sqrt{g L_{o s}}}, \\
C_{b}=\frac{V}{L_{o s} B T}, \\
C_{m}=\frac{A}{B T}, \\
C_{p}=\frac{C_{b}}{C_{m}}, \\
C_{v}=\frac{V}{L_{o s}^{3}} .
\end{gathered}
$$

Yhtälöissä 13-19 $v_{\text {nop }}$ on aluksen nopeus, $v_{k i n}$ veden kinemaattinen viskositeetti, $g$ painovoimakiihtyvyys, $L_{w l}$ vesilinjan pituus, $L_{o s}$ hydrodynaaminen pituus, $V$ uppouma, $B$ leveys, $T$ syväys ja $A$ keskilaivankaaren pinta-ala. Keulabulbin vastusta alentava vaikutus arvioidaan ROPAX-aluksille johdetulla yhtälöllä [58] 


$$
10^{3} \Delta C_{b l}=-0,2-1,1 F_{n}
$$

pinnankarheusefekti $\left(\Delta C_{f}\right)$ pinnankarheuden $k_{s}$ suhteen [59] yhtälöllä

$$
10^{3} \Delta C_{f}=0,044\left(\sqrt[3]{\frac{k_{s}}{L_{w l}}}-\frac{10}{\sqrt[3]{R_{n}}}\right)+0,000125
$$

ja pinnankarheusyhtälön kanssa käytettävällä skaalauskertoimella $\left(\Delta C_{a}\right)$

$$
10^{3} \Delta C_{a}=5,68-0,6 \log _{10} R_{n}
$$

Aluksen pohjan märkäpinta-ala arvioidaan kaksipotkuriselle, akselivetoiselle ROPAXalukselle soveltuvalla yhtälöllä [59]

$$
S_{\text {ropax }}=1,21\left(\frac{V}{T}+1,3 L_{w l} T\right)\left(1,2-0,34 C_{b}\right) .
$$

\section{Kulkudatan analysointi Naiivi Bayes -menetelmällä}

Aluksen lastauksella on vaikutusta kulkuvastukseen niin DWT:n kuin trimminkin muutosten kautta, erityisesti laskettaessa aluksen energiankulutusta tonnimailia kohden. Tässä tutkimuksessa tutkimuskohteena oleva ROPAX lastataan ja puretaan peräportin kautta. Ajetulla reitillä aluksen lastitilanne on yleensä suhteellisen hyvin ennakoitavissa. Esimerkiksi ajanjaksolla 19.7-3.9.2018 DWT vaihteli välillä 5302-9264 tonnia (max. 9653 t), keskiarvon ollessa 7749 t, keskihajonnan $961 \mathrm{t}$ ja mediaanin 7863 t, kulkusyväyksen asettuessa tuolloin 6,5-7,1 metriin. Aluksen trimmi lastauksen tapahduttua on yleensä varsin tasapainoinen, tosin rahtitilan painottuessa ahteriin alus jää helpommin lievään perätrimmiin (satamatrimmin keskiarvo $0,04 \mathrm{~m}$, keskihajonta $0,16 \mathrm{~m}$ ja mediaani $0,1 \mathrm{~m}$ ). Valitulla ajanjaksolla Vuosaaren satamassa trimmaus oli paremmin ennakoitavissa (keskiarvo 0,1 $\mathrm{m}$, keskihajonta $0,11 \mathrm{~m}$ ja mediaani $0,11 \mathrm{~m}$ DWT:n keskiarvon ollessa $7523 \mathrm{t}$, keskihajonnan 909 t ja mediaanin 7655 t) siinä missä Skandinavienkailla arvoissa ilmeni vähän enemmän eroavuutta (keskiarvo -0,02 m, keskihajonta $0,18 \mathrm{~m}$ ja mediaani 0,04 m DWT:n keskiarvon ollessa 7990 t, keskihajonnan $986 \mathrm{t}$ ja mediaanin $8561 \mathrm{t}$ ). Trimmidatassa on tosin kyseisen laivatyypin osalta aluksen järjestelmistä johtuvaa systeemistä vinoumaa, minkä vuoksi esitettyihin trimmilukemiin pitää suhtautua asianmukaisella varauksella.

Artikkelisarjan edellisessä artikkelissa [53] perehdyttiin 9.-10.8.2018 tallentuneeseen dataan, missä alus kohtasi nopeasti voimistuvan tuulirintaman Gotlannin lähistöllä. Luodaan datasta kuvan 4 mukainen Naiivi Bayes -malli akselitehon, aluksen nopeuden, trimmin, DWT:n, laskennallisen hyötysuhteen ja tonnimailikohtaisen (DWT) energiankulutuksen dataan perustuen. Akseliteho on tallentunut potkurinakseleiden torsiometreiltä akseligeneraattoreiden jälkeen, aluksen nopeus on GPS-järjestelmästä tallentunut nopeus pohjan suhteen, dynaaminen trimmidata on tallentunut aluksen syväysantureilta ja DWT 
on todettu aluksen lähtiessä merelle. Laskennallinen hyötysuhde on laskennallisen kulkuvastuksen (yhtälöt 9-23) ja tallentuneen akselitehon suhde:

$$
\mu_{\text {lask. }}=\frac{R_{T} v_{n o p}}{P_{D}}
$$

Aluksen energiankulutus on määritelty akseleiden käyttämän energian (kWh), DWT:n (t) ja kuljetun matkan (NM) suhteena. Valitaan Chow-Liu-puun luokkamuuttujaksi energiankulutus ja lasketaan vahvimmat painokertoimet akselitehon suhteen. Minuutin välein tallentunut data diskretisoidaan tasajakaumaperiaatteella siten, että akselitehodata, laskennallinen hyötysuhde, nopeus ja energiankulutus jakautuvat kukin 25 luokkaan. Trimmidatan arvioidaan saavuttavan riittävän tarkkuuden 10 luokan tasajakaumaa soveltamalla. Data sovitetaan luotuun malliin soveltaen Lauritzenin EM-algoritmia [60, 61]. Voimakkaimmat vuorovaikutukset ovat nopeusdatan ja laskennallisen hyötysuhteen, nopeuden ja trimmin, sekä akselitehon ja trimmin datajoukkojen välillä.

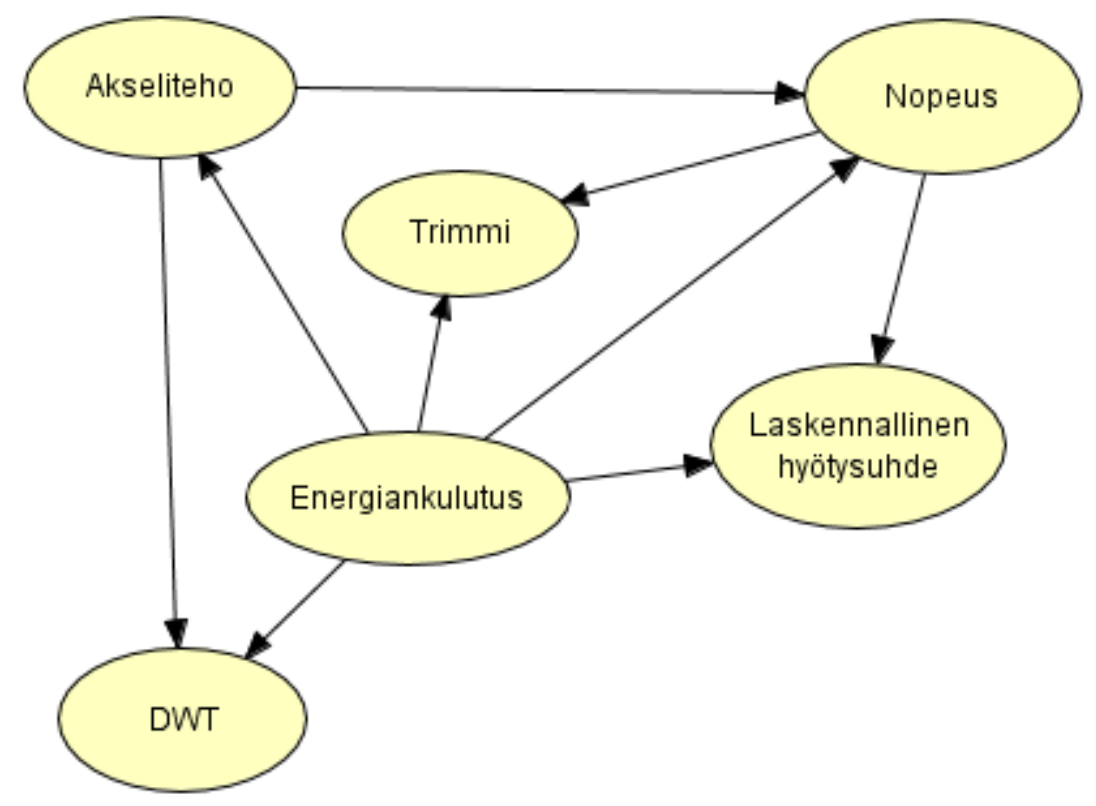

Kuva 4. Naiivi Bayes -verkon vuorovaikutussuhteet

Laskennallisen hyötysuhteen datajoukko sisältää paljon informaatiota olosuhteista, joissa alus tosiasiassa kulkee. Kuten on todettu artikkelissa [53], sääolosuhteiden vaikutus aluksen kulkuun on merkittävä ja suoraan siitä on saatavissa ainoastaan rajoitetusti dataa. Kuvasta 5 voidaan kuitenkin jo visuaalisestikin päätellä, että ennen tuulirintaman kohtaamista noin 03:00-04:00 UTC on tuuli mahdollisesti ollut puuskaista (tai alueella on tapahtunut muita aluksen kulkuun vaikuttavia ilmiöitä). Koko tarkasteluajanjaksolla nopeus on pysynyt suhteellisen tasaisena keskiarvon ja mediaanin ollessa 22,3 solmua ja keskihajonnan 0,3 solmua. Vastaavasti tuulirintama näkyy hyötysuhteen selkeänä heikkenemisenä tehon kuluessa lisääntyneeseen tuulivastukseen. 


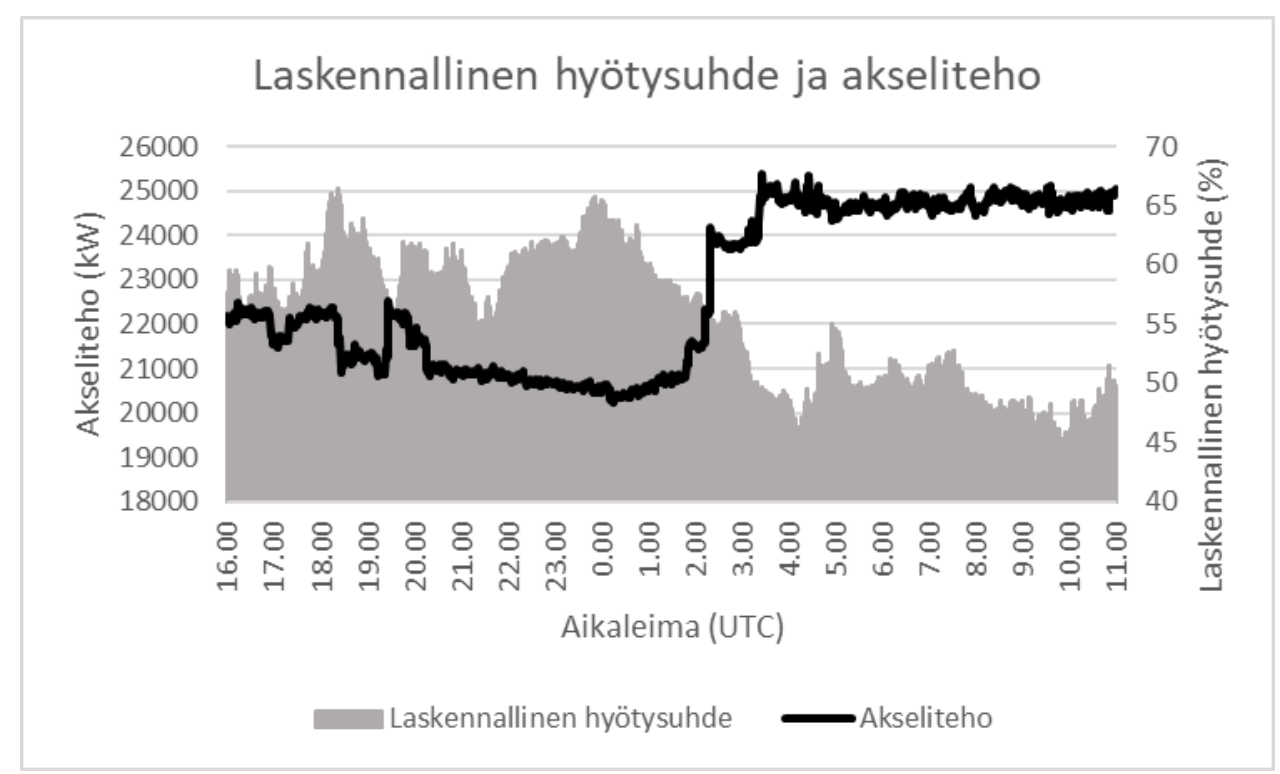

Kuva 5. Laskennallinen hyötysuhde ja akseliteho

Havainnointijaksolla akselitehon data on diskretisoitu tasajakaumaperiaatteella kuvassa 6 esitettyihin luokkiin. Data tehoalueelta $20332 \ldots 22389 \mathrm{~kW}$ on jaettu 11 luokkaan edustaen 53,35 \% koko tallentuneesta tehodatasta. Vastaavasti kolmeen luokkaan tehoalueella $24447 \ldots 25008 \mathrm{~kW}$ sijoittuu 39,97\% datasta, jolloin kuvassa 6 on esitetty yhteensä 93,32 \% ajanjaksolta luokitetusta akselitehodatasta. Loput datasta sijoittuu välille $22389 . .24447 \mathrm{~kW}$, mutta tällä välillä luokkakohtainen data on määrällisesti vähäistä. Tällä on merkitystä, koska valitulla diskretisoinnilla on vaikutusta lopputuloksiin muun muassa siten, että hyvin pieni luokka todennäköisemmin edustaa erikoistapausta, jolloin analyysin luotettavuus heikkenee. Vastaavasti liian suurin luokin toteutettu diskretisointi voi kätkeä todellisuudessa tapahtuvia ilmiöitä luokkarajojen sisään, jolloin ne eivät välttämättä ilmene analyysin tuloksissa. Verrattaessa kuvan 6 jakaumaa kuvan 5 akselitehokäyrään, voi tehon jakautumisen esitettyihin diskretisointiluokkiin havaita myös visuaalisesti.

Kuvassa 7 on esitetty tallentuneesta trimmidatasta 94,24\%, kuvassa 8 nopeusdatasta $89,21 \%$ ja kuvassa 9 laskennallinen hyötysuhdedata kokonaisuudessaan. Trimmin vaihtelu on varsin vähäistä asettuen pääasiassa noin 0,15 m lukualueen sisään. Nopeusdatasta on havaittavissa normaalijakautuminen, mikä onkin odotettavaa ajettaessa linjaliikenteessä aikataulun mukaisella vakionopeudella. Laskennallinen hyötysuhde jakautuu selkeästi kahteen segmenttiin, missä 42,29\% datasta asettuu lukualueelle 44,52 ..54,15\% ja $57,73 \%$ datasta lukualueelle $54,15 \ldots 66,42 \%$. Vastaava jakautuneisuus on havaittavissa myös kuvassa 10 esitetyssä energiankulutusdatan jakaumassa, missä on esitetty 94,25\% energiankulutusdatasta jakautuneena kahteen segmenttiin siten, että lukualueella $0,1215 \ldots 0,1357 \mathrm{kWh} /(\mathrm{DWT} \cdot \mathrm{NM})$ datasta on $53,47 \%$ ja lukualueella $0,1457 \ldots 0,1570$ $\mathrm{kWh} /(\mathrm{DWT} \cdot \mathrm{NM}) 40,78 \%$. 


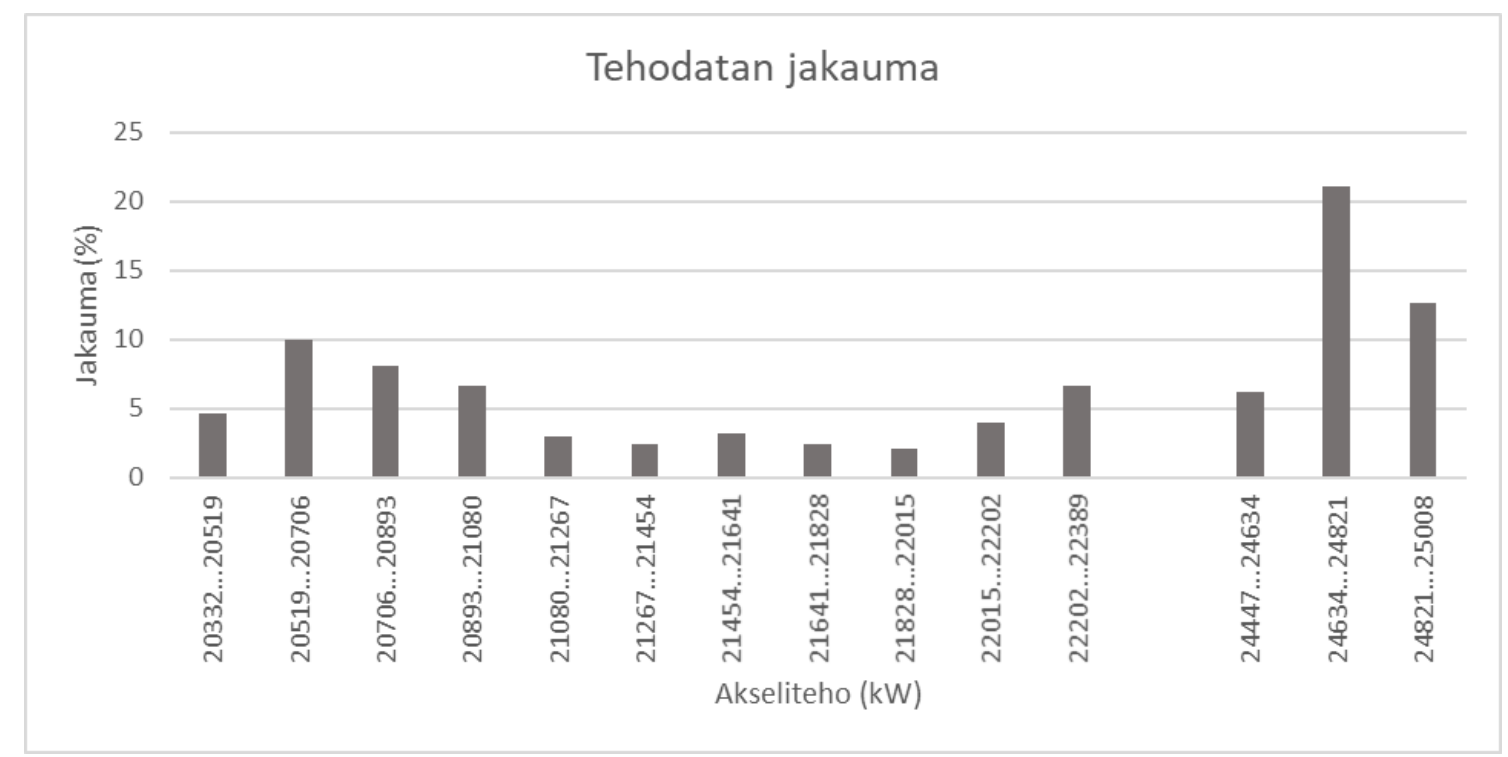

Kuva 6. Akselitehodata diskretisoituna

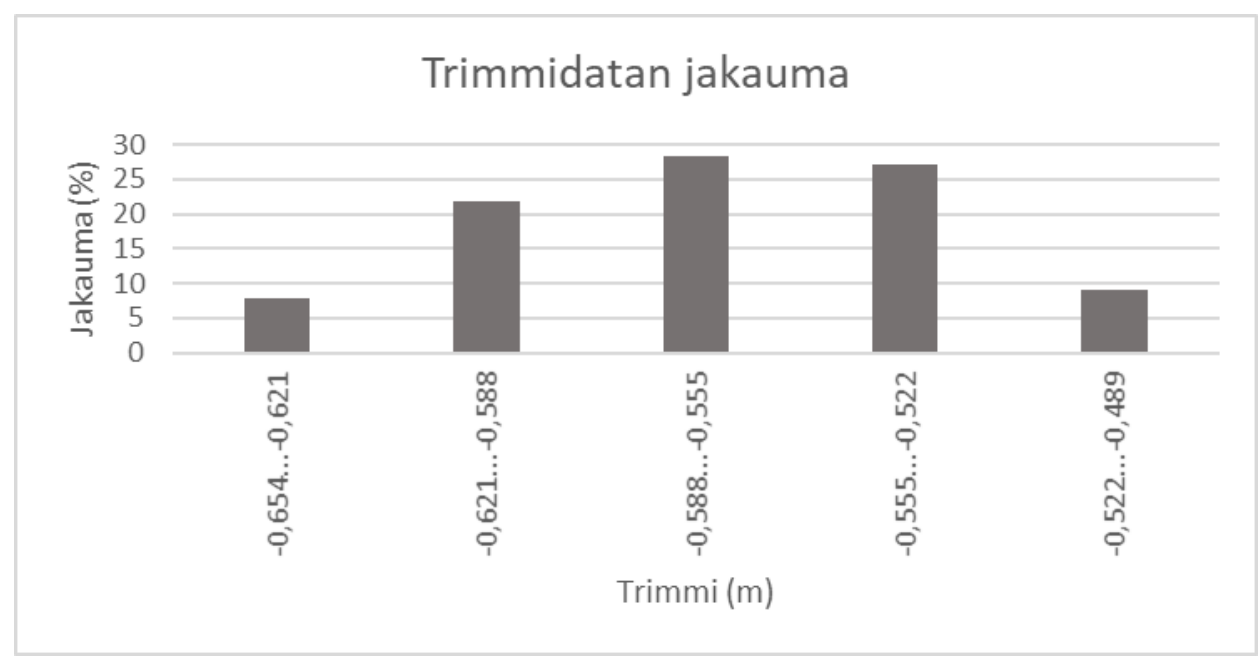

Kuva 7. Trimmidata diskretisoituna

Edellä kuvatuista taulukoista on sellaisenaan hankala tehdä luotettavia päätelmiä. Naiivi Bayes -menetelmän avulla voidaan kuitenkin eri datajoukkojen vuorovaikutusta analysoida tehokkaasti. Otetaan tarkemman analyysin kohteeksi datan sisältämä informaatio, kun akseliteho on vaihdellut lukualueella $20519 . .20706 \mathrm{~kW}$. Tämä data edustaa 10,04 $\%$ koko akselitehodatasta. Valittua akselitehojakaumaa vastaava nopeusdata jakautuu kuvassa 11 osoitetulla tavalla sisältäen 99,48 \% valitulle tehoalueelle liittyvästä nopeusdatasta. Trimmin, energiankulutuksen ja laskennallisen hyötysuhteen jakaumien tiheydeltään neljä suurinta luokkaa on esitetty taulukossa 1 . 


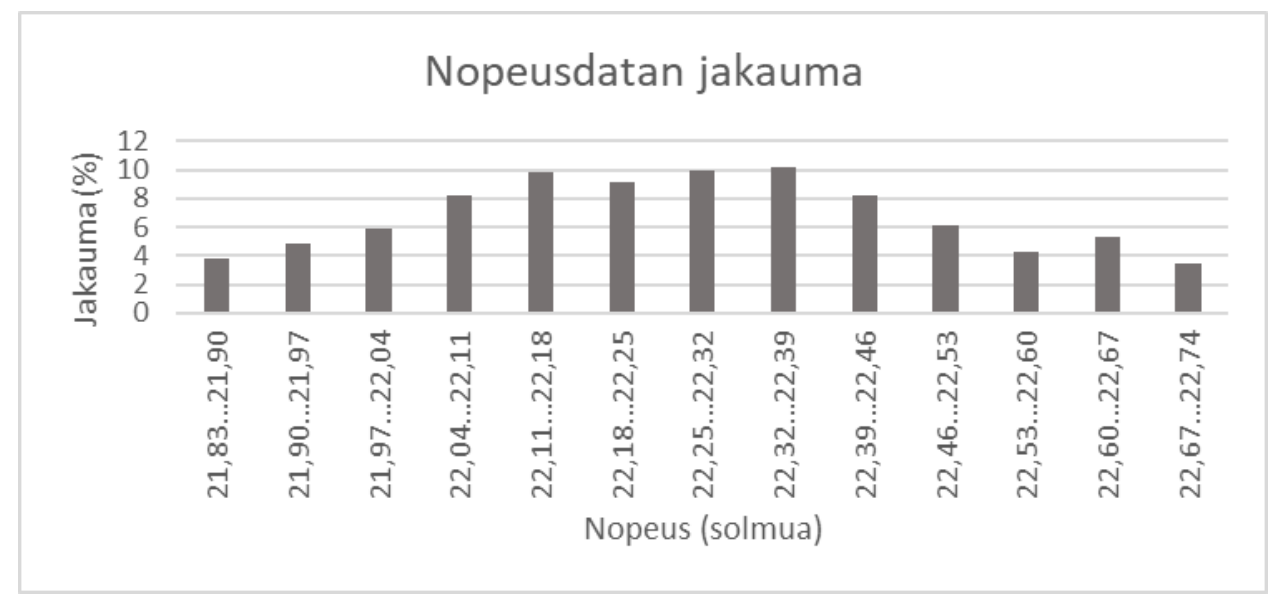

Kuva 8. Nopeusdata diskretisoituna

\section{Hyötysuhdedatan jakauma}

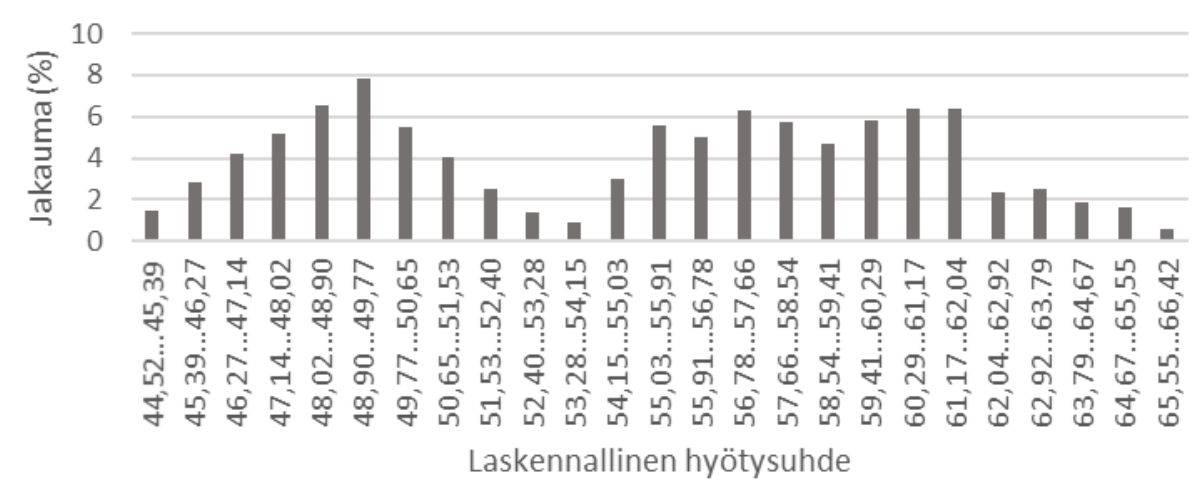

Kuva 9. Laskennallinen hyötysuhdedata diskretisoituna

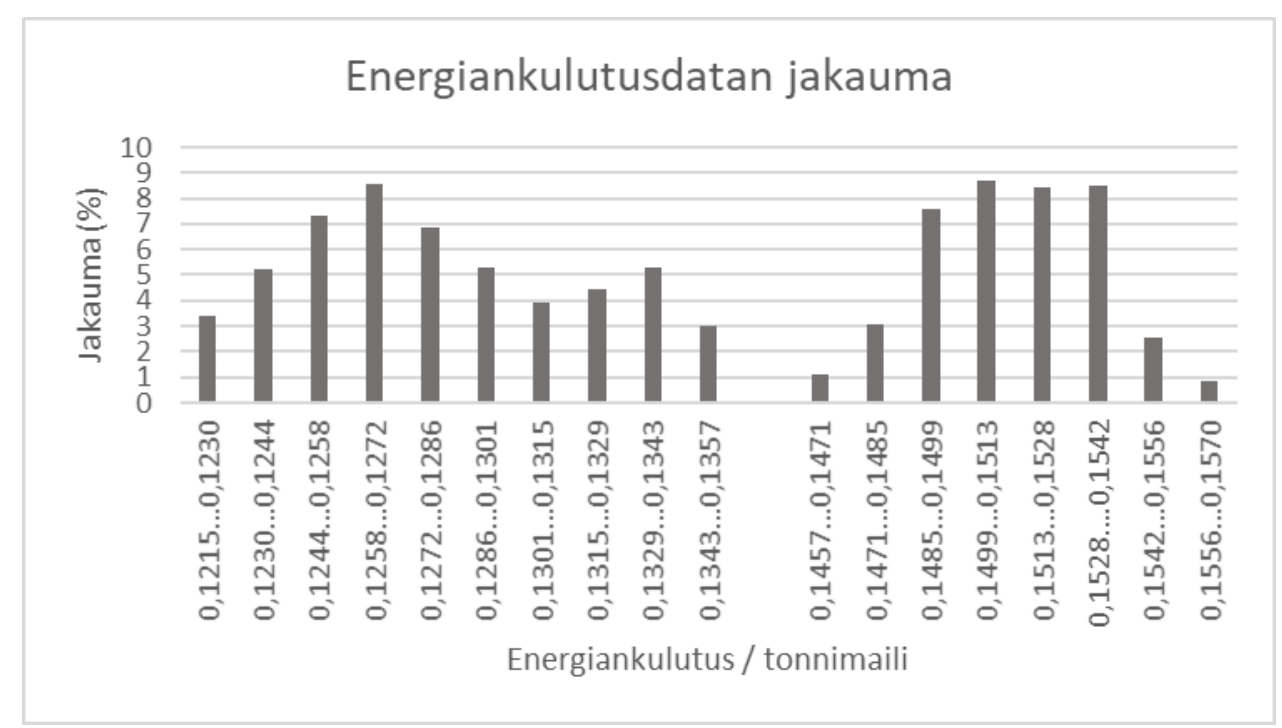

Kuva 10. Energiankulutusdata diskretisoituna 


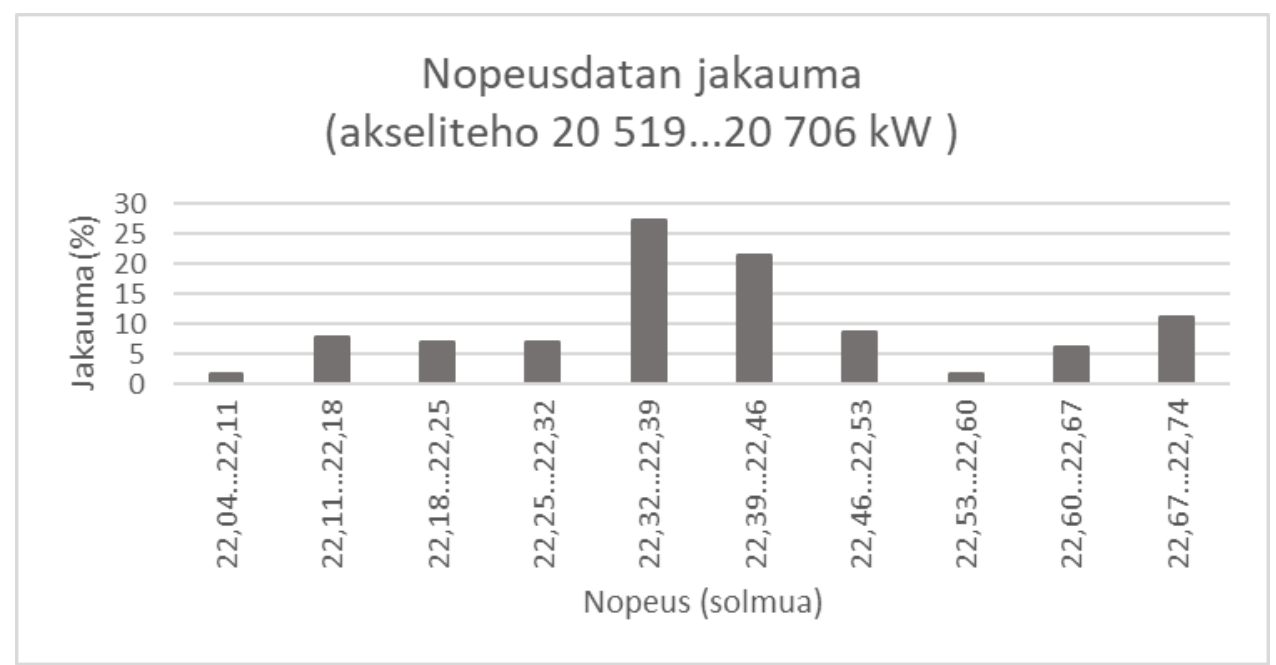

Kuva 11. Nopeusdata akseliteholla $20519 . .20706$ kW

Taulukko 1. Trimmin, energiankulutuksen ja laskennallisen hyötysuhteen datan jakautuminen tehoalueella $20519 \ldots 20706 \mathrm{~kW}$

\begin{tabular}{cccccc}
\hline Trimmi & \multicolumn{2}{c}{ Energiankulutus } & \multicolumn{2}{c}{ Laskennallinen hyötysuhde } \\
\hline $\mathrm{m}$ & $\%$ & $\mathrm{kWh} /(\mathrm{DWT} \cdot \mathrm{NM})$ & $\%$ & $\%$ & $\%$ \\
\hline$-0,621 \ldots-0,588$ & 4,30 & $0,1215 \ldots 0,1230$ & 12,85 & $59,41 \ldots 60,29$ & 12,43 \\
$-0,588 \ldots-0,555$ & 40,38 & $0,1230 \ldots 0,1244$ & 26,53 & $60,29 \ldots 61,17$ & 26,06 \\
$-0,555 \ldots-0,522$ & 51,10 & $0,1244 \ldots 0,1258$ & 57,31 & $61,17 \ldots 62,04$ & 26,96 \\
$-0,522 \ldots-0,489$ & 3,76 & $0,1258 \ldots 0,1272$ & 2,60 & $62,04 \ldots 62,92$ & 8,38 \\
\hline
\end{tabular}

Analysoitaessa aluksen kulkua tehoalueella $20519 . .20706 \mathrm{~kW}$ nopeusalueella $22,32 \ldots 22,39$ solmua jakautuu trimmin, energiankulutuksen ja laskennallisen hyötysuhteen data jo varsin keskittyneesti (taulukko 2). Tuolloin laskentamalli hyödyntää enää 2,7 $\%$ systeemiin syötetystä kokonaisdatasta. Toisaalta tämä osoittaa menetelmän tehokkuuden ja soveltamiskelpoisuuden: Esimerkiksi vallitsevalla nopeudella on varsin suuri painoarvo tuloksiin ja solmunkin eroavuus näkyy tuloksissa jo vahvasti. Tämän vuoksi analysoitaessa pohjan likaantumisesta aiheutuvaa muutosta, minkä suuruusluokka on kuitenkin tässä tilanteessa arviolta noin $5 \%$ aluksen hydrodynaamisesta vastuksesta, on sovellettava riittävän herkkiä analyysimenetelmiä.

Taulukko 2. Trimmin, energiankulutuksen ja laskennallisen hyötysuhteen datan jakautuminen tehoalueella $20519 \ldots 20706 \mathrm{~kW}$, nopeudella 22,32-22,39 solmua

\begin{tabular}{cccccc}
\hline Trimmi & \multicolumn{2}{c}{ Energiankulutus } & \multicolumn{2}{c}{ Laskennallinen hyötysuhde } \\
\hline $\mathrm{m}$ & $\%$ & $\mathrm{kWh} /(\mathrm{DWT} \cdot \mathrm{NM})$ & $\%$ & $\%$ & $\%$ \\
\hline$-0,588 \ldots-0,555$ & 43,39 & $0,1230 \ldots 0,1244$ & 12,49 & $60,29 \ldots 61,17$ & 70,33 \\
$-0,555 \ldots-0,522$ & 51,64 & $0,1244 \ldots 0,1258$ & 87,40 & $61,17 \ldots 62,04$ & 29,43 \\
\hline
\end{tabular}

Valitaan seuraavaksi tarkasteltavaksi luokka $24634 \ldots 24821 \mathrm{~kW}$, minne sijoittuu $21,10 \%$ tallentuneesta akselitehodatasta. Tätä tehoaluetta vastaava nopeusdata on suu- 
ruusluokaltaan hieman alempi verrattuna luokkaan $20519 \ldots 20706$ kW, eli lisää akselitehoa on tarvittu nopeuden säilyttämiseksi sääolosuhteiden muututtua. Nopeusdatan jakauma on esitetty kuvassa 12, sisältäen 13 luokkaa, mitkä edustavat $99 \%$ tälle tehoalueelle liittyvästä nopeusdatasta. Suurimmat datajoukot sijoittuvat nopeusalueelle $22,04 \ldots 22,25$ solmua, nopeusalueen $22,32 \ldots 22,39$ solmua edustaen $9,37 \%$ tehoalueen nopeusdatasta. Tuolloin analyysissä hyödynnetään 2,0 \% systeemiin syötetystä kokonaisdatasta.

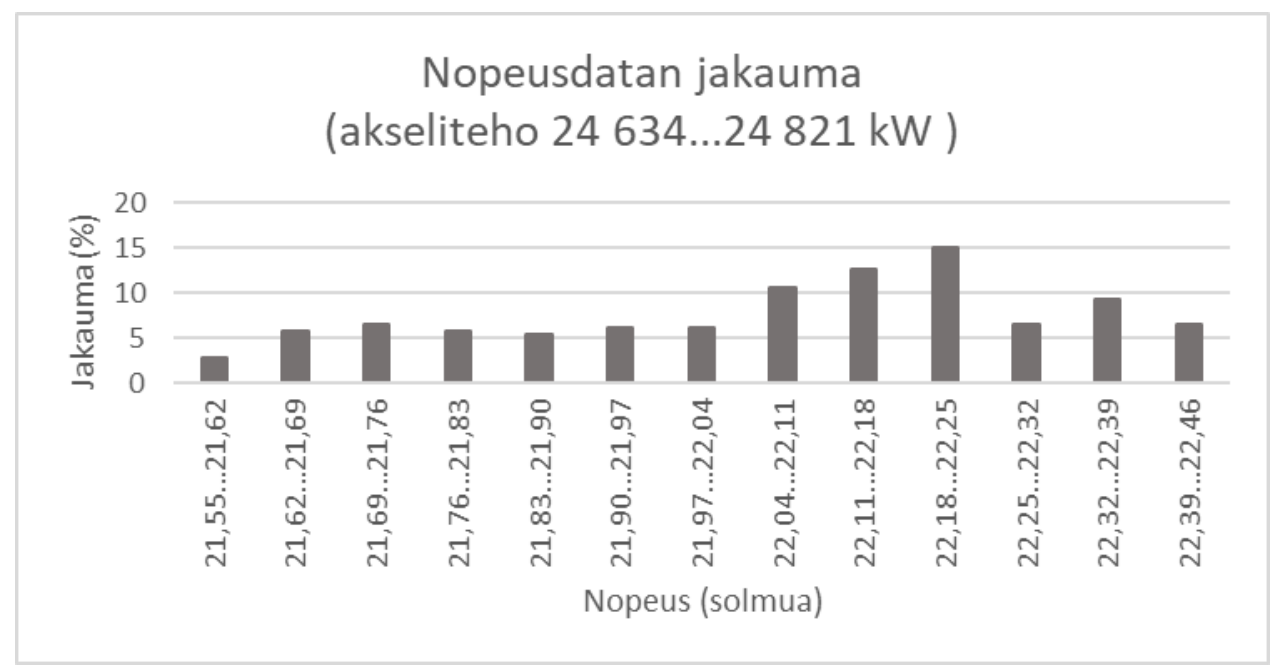

Kuva 12. Nopeusdata akseliteholla $24634 \ldots 24821 \mathrm{~kW}$

Valitulla nopeusalueella trimmin, energiankulutuksen ja laskennallisen hyötysuhteen jakaumien kolme suurinta luokkaa ovat nähtävissä taulukossa 3. Energiankulutuksen ja laskennallisen hyötysuhteen data on keskittynyt hyvinkin selkeästi. Trimmi on selkeästi kasvanut verrattuna taulukoissa 1 ja 2 esitettyihin lukuarvoihin. Vaikka trimmidatan tarkkuus ei olisikaan paras mahdollinen, on havaitussa muutoksessa ilmenevä virhe kuitenkin todennäköisesti suhteellisen lineaarinen, jolloin keulatrimmin lisääntyminen työntövoiman kasvaessa ainakin tällä lastitilanteella on todennäköistä ainakin tämän datajoukon perusteella. Trimmin muutos on joka tapauksessa melko vähäinen, joten tilastollisten päätelmien tekeminen sen muutoksista antaa osviittaa, että menetelmän tarkkuus riittäisi myös pohjan likaantumisesta aiheutuvan kulkuvastuksen analysointiin. Tarkempien päättelyiden tekeminen trimmin muutoksista konetehon suhteen vaatisi luonnollisesti useita eri lastaustilanteissa tehtäviä analyysejä, koska aluksen lastaus vaikuttaa hyvin todennäköisesti työntövoiman ja trimmin väliseen suhteeseen niin määrällisesti (DWT) kuin sijaintinsakin (satamatrimmi) perusteella. Tässä artikkelissa ei kuitenkaan ole tavoitteena trimmin analysointi, joten asiaan ei perehdytä tämän tarkemmin. Lisäksi tuolloin aluksen trimmiä analysoivien mittalaitteiden tuottaman datan tulisi olla mahdollisimman laadukasta.

Kulkuvastuksen herkkyydestä DWT:n muutoksille saadaan käsitys tarkastelemalla aluksen kulkua kahdella valitulla legillä. Ensimmäisen legin tallenteet ovat esitetty kuvissa 13 ja 14, alkaen 21.7.2018 kello 12:00 (UTC) ja päättyen 22.7 kello 03:00 (UTC). Aluksen ilmoitettu DWT on ollut 8656 tonnia. Pintavirtaukset ovat ajanjaksolla olleet 
heikot $(0,1 \ldots 2,5 \mathrm{~cm} / \mathrm{s})$ suunnan ollessa aluksen kulkusuuntaa vastaan, tosin todennäköisesti Ölands södra grundin ja Hoburgin matalan lähistöllä virtaukset ovat saattaneet olla voimakkaampia. Ainakin sekä nopeus- että hyötysuhdekäyrässä on nähtävissä selkeät muutokset aikaleimojen 14:00 ja 16:00 tietämillä, jolloin alus on AIS-tietojen perusteella sijainnut näillä merialueilla. Tosin aiheuttajana voi olla myös matala meri tai ainakin Hoburgin tapauksessa rannikon läheisyydestä johtuvat, avomereen verrattuna poikkeavat tuuliolosuhteet. Tuulet ovat olleet koko legillä myötäisiä, tuulen keskimääräisen voimakkuuden ollessa rannikkoasemilla (Utklippan, Ölands södra udde, Hoburg, Östergarnsholm, Gotska sandön, Mäkiluoto) pääasiassa $3 \ldots 6 \mathrm{~m} / \mathrm{s}$. Suomenlahdella tuuli on ollut ajoittain voimakkaampaa mutta myötäistä (todennäköisesti merellä noin $10 \mathrm{~m} / \mathrm{s}$ ), mikä näkyy konetehon vähenemisenä nopeuden pysyessä silti suhteellisen vakiona.

Taulukko 3. Trimmin, energiankulutuksen ja laskennallisen hyötysuhteen datan jakautuminen tehoalueella $24634 \ldots 24821 \mathrm{~kW}$, nopeudella 22,32-22,39 solmua

\begin{tabular}{cccccc}
\hline Trimmi & \multicolumn{2}{c}{ Energiankulutus } & \multicolumn{2}{c}{ Laskennallinen hyötysuhde } \\
\hline $\mathrm{m}$ & $\%$ & $\mathrm{kWh} /(\mathrm{DWT} \cdot \mathrm{NM})$ & $\%$ & $\%$ & $\%$ \\
\hline$-0,69 \ldots-0,65$ & 10,21 & $0,1471 \ldots 0,1485$ & 17,36 & $49,77 \ldots 50,65$ & 6,47 \\
$-0,65 \ldots-0,62$ & 33,33 & $0,1485 \ldots 0,1499$ & 69,46 & $50,65 \ldots 51,53$ & 90,15 \\
$-0,62 \ldots-0,59$ & 43,18 & $0,1499 \ldots 0,1513$ & 13,03 & $51,53 \ldots 52.40$ & 2,89 \\
\hline
\end{tabular}

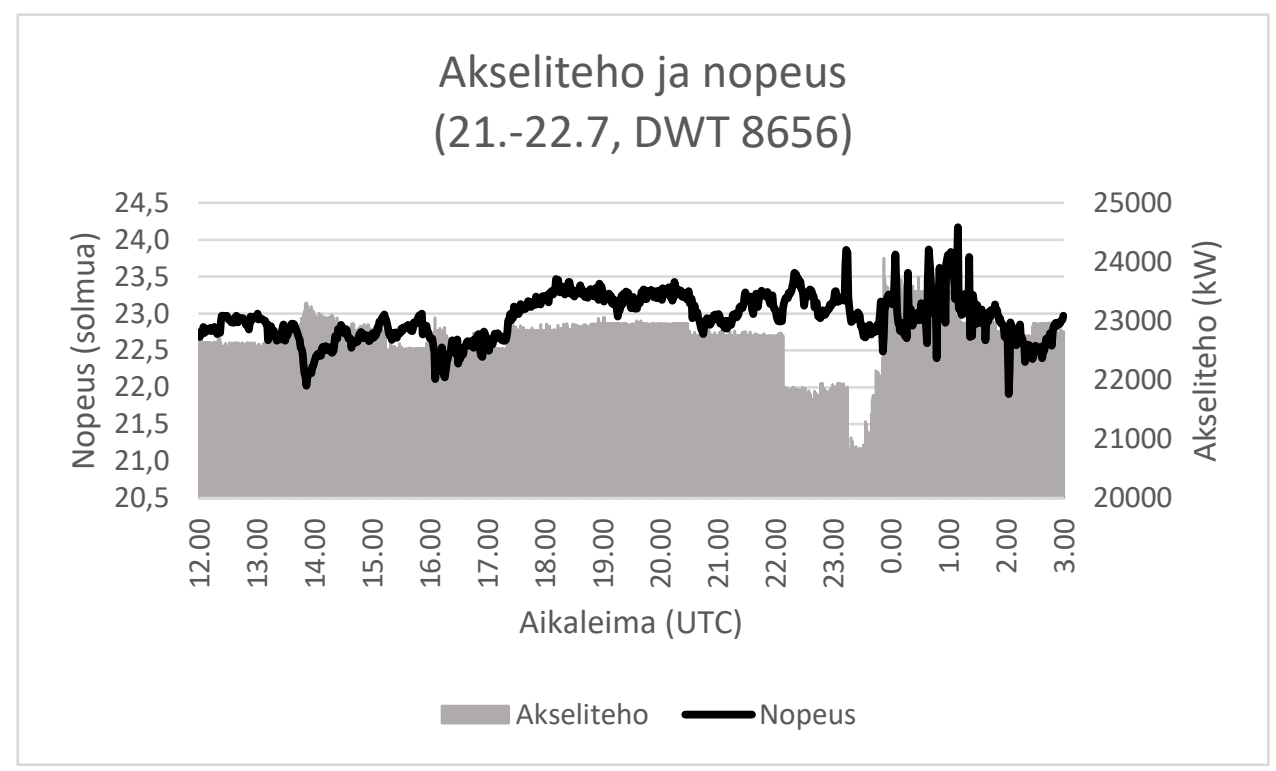

Kuva 13. Akseliteho ja nopeus 21.-22.7.

Esitetyllä legillä laskennallisen hyötysuhteen ja nopeusdatan Pearsonin korrelaatiokerroin on 0,92 , mikä kertoo voimakkaasta positiivisesta korrelaatiosta näiden datajoukkojen välillä. Sitä vastoin akselitehon ja nopeusdatan korrelaatio on vain 0,01 . Todellisuudessa näiden välillä on luonnollisesti vahva korrelaatio, mutta se ei tässä tule ilmi nopeusvaihtelun ollessa vain vähäistä ja myötätuulen antaessa aika-ajoin alukselle lisää vauhtia. Laivan laskennallinen hyötysuhde ja energiankulutus tonnimailia kohden on esitetty kuvassa 14. 


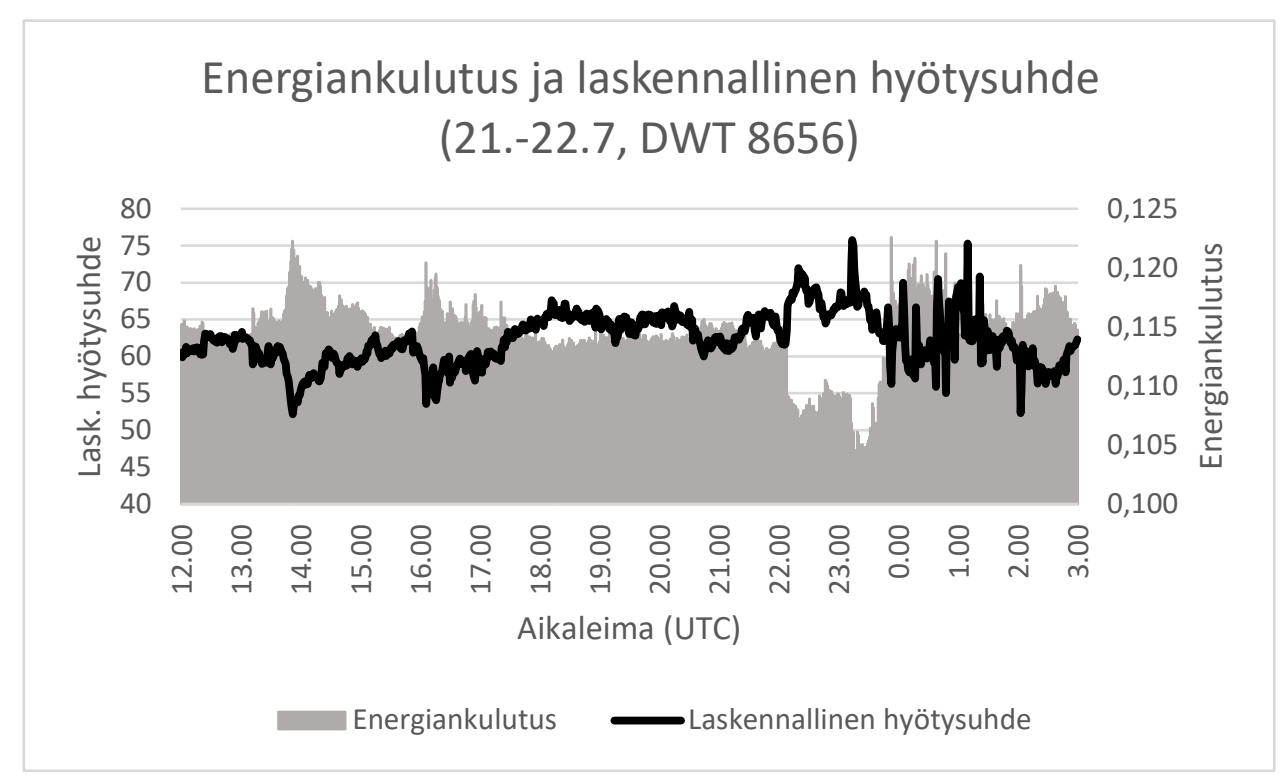

Kuva 14. Energiankulutus ja laskennallinen hyötysuhde 21.-22.7.

Kahta päivää myöhemmin (24.-25.7) aluksen ilmoitettu DWT on ollut 7074 tonnia, eli alus on ollut selkeästi kevyemmin lastattuna. Virtaukset ovat pääsääntöisesti olleet heikkoja $(0,1 \ldots 2,5 \mathrm{~cm} / \mathrm{s})$ suuntautuessa aluksen kulkusuuntaa vasten, tosin Suomenlahdella ja Bornholmin altaalla alus on mahdollisesti ajanut jopa $5 \ldots 10 \mathrm{~cm} / \mathrm{s}$ vastavirrassa. Tuuliolosuhteet ovat olleet legin ensimmäisellä puolikkaalla myötäiset (rannikkoasemien tuulen nopeustallenteet noin 2-6 m/s) tuulen suunnan kääntyessä legin puolivälissä asteittain lounaasta kaakkoon. Laskennallisen hyötysuhteen ja nopeuden korrelaatiokerroin on 0,67, siinä missä akseliteho ja nopeusdata korreloivat voimakkuudella 0,47 . Edellistä esimerkkiä vastaavat käyrät on esitetty kuvissa 15 ja 16.

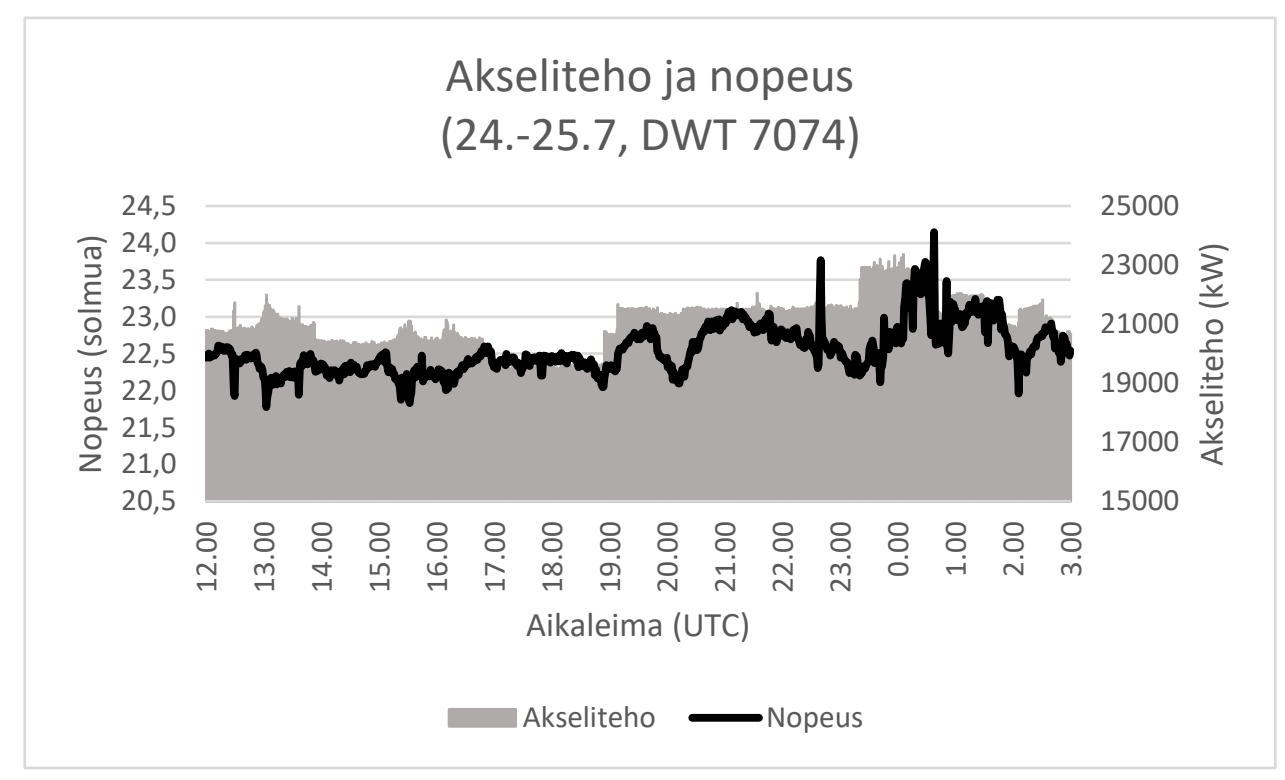

Kuva 15. Akseliteho ja nopeus 24.-25.7. 


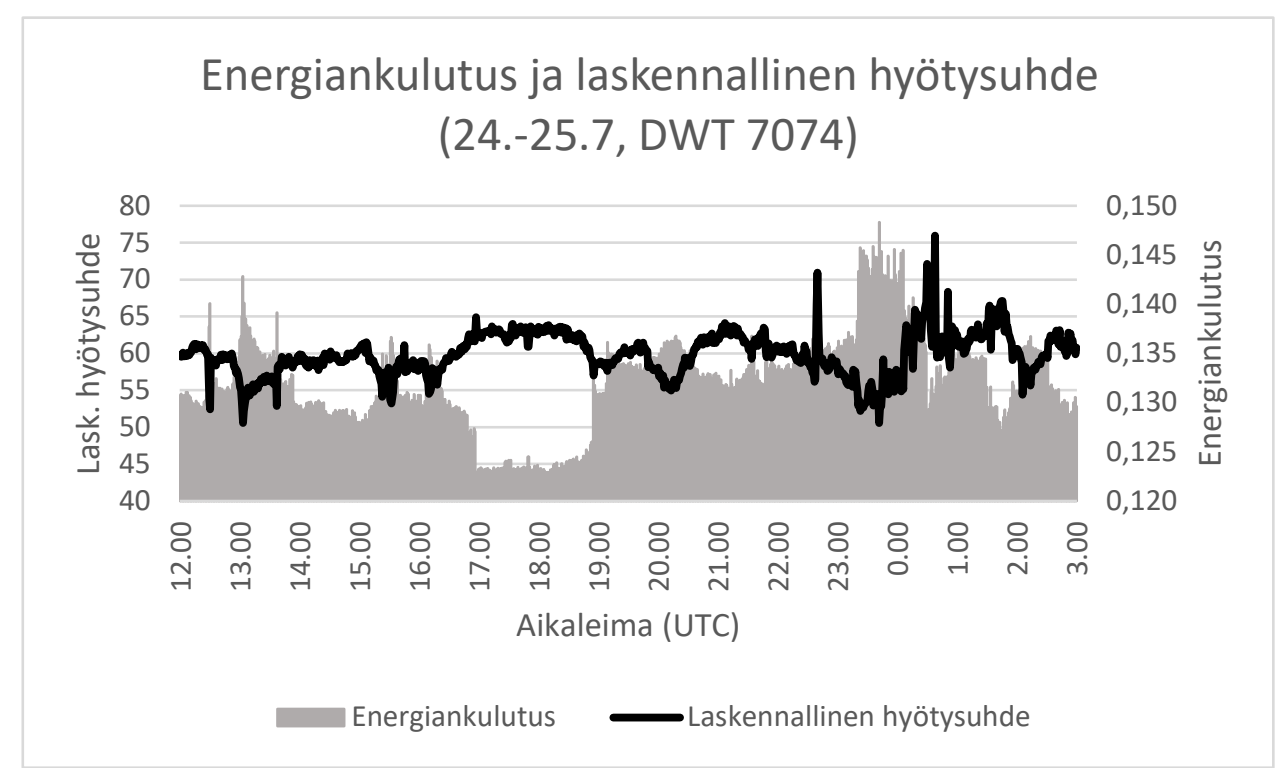

Kuva 16. Energiankulutus ja laskennallinen hyötysuhde 24.-25.7.

Laivan vauhti on ollut jonkin verran nopeampi legillä, jolla DWT on ollut 8656 tonnia. Tuolloin nopeusdatan keskiarvo on ollut 22,94, mediaani 22,93 ja hajonta 0,31 solmua. Toisella legillä (DWT 7074 tonnia) vastaavat arvot ovat olleet 22,55, 22,47 ja 0,33 solmua. Akselitehon keskiarvo on ollut 21.-22.7. ajetulla legillä $22725 \mathrm{~kW}$ ja hajonta 488 kW, siinä missä 24.-25.7. akselitehon keskiarvo on $21034 \mathrm{~kW}$ ja hajonta $862 \mathrm{~kW}$. Tällä tavalla dataa tarkasteltuna on kuitenkin vaikea sanoa, mikä osuus tehoerosta mahdollisesti johtuisi kulkunopeuden muutoksesta ja mikä muuttuneesta lastaustilanteesta huomioiden etenkin muuttuvat ympäristöolosuhteet. Hyödyntämällä edellä kuvatulla tavalla Naiivi Bayes -menetelmää voidaan data luokitella taulukoissa 4 ja 5 esitetyllä tavalla.

Taulukko 4. Nopeuden ja DWT:n vaikutus vaadittavaan akselitehoon (DWT 7074)

\begin{tabular}{cccc}
\hline $\begin{array}{c}\text { Tehoalue } \\
(\text { DWT } 7074 \mathrm{t})\end{array}$ & $\begin{array}{c}22,54-22,65 \\
\text { solmua }\end{array}$ & $\begin{array}{c}22,65-22,76 \\
\text { solmua }\end{array}$ & $\begin{array}{c}22,76-22,87 \\
\text { solmua }\end{array}$ \\
\hline $20631 \ldots 20917 \mathrm{~kW}$ & $22,92 \%$ & $5,88 \%$ & $6,49 \%$ \\
$20917 \ldots 21203 \mathrm{~kW}$ & $3,46 \%$ & $4,42 \%$ & $6,49 \%$ \\
$21203 \ldots 21490 \mathrm{~kW}$ & $6,89 \%$ & $30,75 \%$ & $31,05 \%$ \\
$21490 \ldots 21776 \mathrm{~kW}$ & $45,82 \%$ & $45,38 \%$ & $38,81 \%$ \\
\hline
\end{tabular}

Taulukko 5. Nopeuden ja DWT:n vaikutus vaadittavaan akselitehoon (DWT 8656)

\begin{tabular}{cccc}
\hline $\begin{array}{c}\text { Tehoalue } \\
(\text { DWT } 8656 \mathrm{t})\end{array}$ & $\begin{array}{c}22,54-22,65 \\
\text { solmua }\end{array}$ & $\begin{array}{c}22,65-22,76 \\
\text { solmua }\end{array}$ & $\begin{array}{c}22,76-22,87 \\
\text { solmua }\end{array}$ \\
\hline $22348 \ldots .22634 \mathrm{~kW}$ & $38,64 \%$ & $32,38 \%$ & $36,94 \%$ \\
$22634 \ldots 22920 \mathrm{~kW}$ & $41,61 \%$ & $43,75 \%$ & $46,17 \%$ \\
$22920 \ldots 23206 \mathrm{~kW}$ & $17,85 \%$ & $11,39 \%$ & $3,71 \%$ \\
\hline
\end{tabular}

Taulukoista 4 ja 5 nähdään akselitehodatan jakautuminen valituille nopeusalueille kahdella eri lastaustilanteella. Raskaammassa lastissa liikkuvan aluksen tehontarve on 
selkeästi suurempi verrattuna saavutettuun nopeuteen: Nopeusalue 22,54-22,65 solmua saavutetaan 45,82 \% todennäköisyydellä tehoalueella ollessa $21490 \ldots 21776 \mathrm{~kW}$ DWT:n ollessa 7074 tonnia. Vastaavasti 8656 tonnin lastilla 41,61 \% todennäköisyydellä sama nopeusalue vaatii $22634 \ldots 22920 \mathrm{~kW}$. Toisaalta jakaumasta voidaan havaita, että kevyemmällä lastilla 22,92 \% datasta kohdistuu valitulla nopeusalueella teholuokkaan $20631 \ldots 20917 \mathrm{~kW}$, siinä missä raskaammassa lastissa akselitehodata on tasaisemmin jakautunutta. Myöskään nopeuden kasvaminen ei suoraviivaisesti johda suuremmalle tehoalueelle siirtymiseen johtuen ympäristön olosuhteista, mitkä vaikuttavat suoraan aluksen kulkuun. Tähän saataisiin mitä todennäköisemmin lisää ennustettavuutta valitsemalla analyysiin ainoastaan sellaisten legien data, jolloin ympäristövaikutukset voidaan arvioida mahdollisimman minimaalisiksi.

Testataan seuraavaksi menetelmän soveltuvuutta pohjan likaantumisen havainnointiin valitsemalla analysoitavaksi kulkudataa kahdelta legiltä ennen ja jälkeen pohjan puhdistuksen. Analysoitavaksi valitaan kaksi $12 \mathrm{~h}$ datasettiä, jotka ovat tallentuneet 24.7 ajanjaksolla 11:00 ..23:00 UTC ja 28.-29.7 ajanjaksolla 23:00 ...11:00 UTC. Ensimmäisellä legillä aluksen ilmoitettu DWT on ollut $7074 \mathrm{t}$ ja toisella $7037 \mathrm{t}$ keulatrimmin vaihdellessa pääasiassa lukualueella $0,4 \ldots 0,5 \mathrm{~m}$. Molemmilla legeillä sääolosuhteet ovat olleet analyysiä varten suhteellisen suotuisat: Merkittäviä virtauksia ei alueella ole esiintynyt ja keskimääräiset rannikkosääasemien tallentamat tuulten nopeudet ovat vaihdelleet lukualueella $0,5 \ldots 7,7 \mathrm{~m} / \mathrm{s}$. Aluksen pohja on puhdistettu ensimmäisen legin jälkeen 25.7 aiemman puhdistusajankohdan ollessa kuukautta aiemmin, 25.6. Valitsemalla analysoitavaksi kulutus, syväys, trimmi, likaantumisaste, energiankulutus, akseliteho, laskennallinen hyötysuhde ja nopeus pohjan suhteen, saadaan datasta havainnoitua Naiivi Bayes menetelmää soveltaen kuvassa 17 osoitetut riippuvuussuhteet. Täydentämällä systeemiä datalla aluksen kurssista, tuulen suunnasta ja -nopeudesta sekä potkureiden nousuista, on tuloksena kuvassa 18 visualisoitu systeemi.

Viiteen nopeusluokkaan diskretisoidusta tuulidatasta 23,08 \% sijoittuu luokkaan alle $2,34 \mathrm{~m} / \mathrm{s}$. Tässä tuulennopeusluokassa muu data jakautuu puhdistetun ja likaisen pohjan välillä nopeusluokissa $22,17 \ldots 22,25,22,25 \ldots 22,33$ ja $22,33 \ldots 22,41$ solmua suhteessa $55,02 / 44,98 \%, 54,53 / 45,47 \%$ ja 36,53/63,47\% (kuvassa 18 esitetty systeemi). Vastaavat jakaumat ovat kuvassa 17 osoitetussa systeemissä 59,72/40,28 \%, 46,74/53,26 \% ja $45,05 / 54,95 \%$. Puhtaalla pohjalla tallentunut data painottuu enemmän hitaammille nopeuksille (n. 22 solmua) siinä missä likaisemmalla pohjalla ajettaessa nopeutta on ollut keskimäärin noin 22,5 solmua. Nämä kolme nopeusluokkaa sisältävät kuitenkin merkittävästi dataa molemmista tapauksista, mutta näitä nopeusluokkia hitaammissa painottuu selkeästi puhtaalla pohjalla tallentunut data siinä missä suuremmilla nopeusluokilla painottuu likaisella pohjalla tallentunut data. Painotuseron kasvaessa myös tuloksiin muodostuva vinouma todennäköisesti kasvaa. Kuvan 18 systeemissä nopeusdatasta 12,64 \% sijoittuu luokkaan 22,17...22,25 solmua, 10,78 \% luokkaan 22,25...22,33 solmua ja $12,69 \%$ luokkaan 22,33...22,41 solmua. Vastaavasti kuvassa 17 osoitetussa systeemissä vastaaviin nopeusluokkiin sijoittuu $11,74 \%, 13,04 \%$ ja 11,60 \% datasta. Tehodatan jakaumat on esitetty kuvissa $19 . .21$, laskennallisen hyötysuhdedatan jakaumat kuvissa $22 . .24$ ja energiankulutuksen jakaumat kuvissa $25 \ldots 27$. 


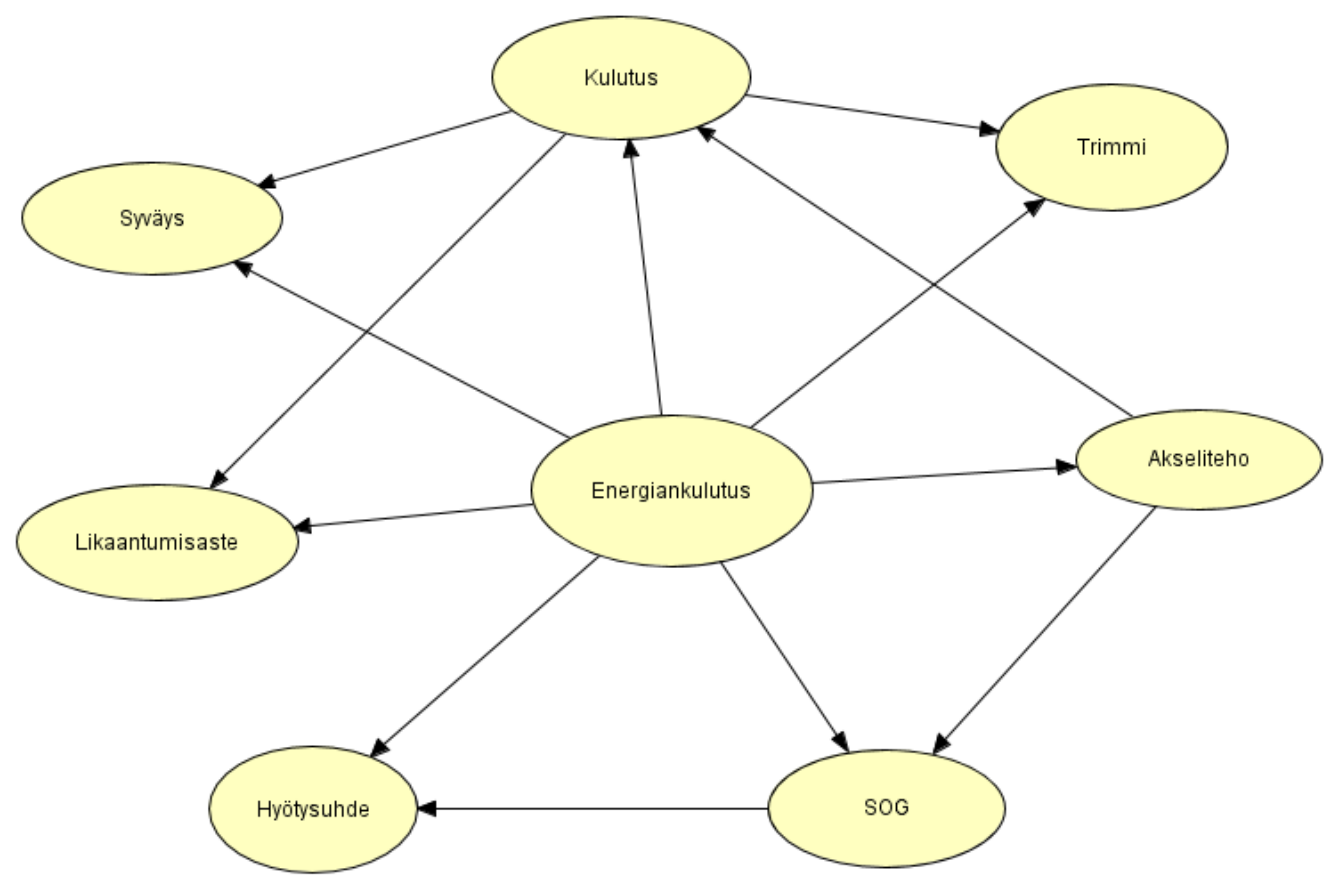

Kuva 17. Systeemin riippuvuussuhteet (ei tuuliolosuhteita)

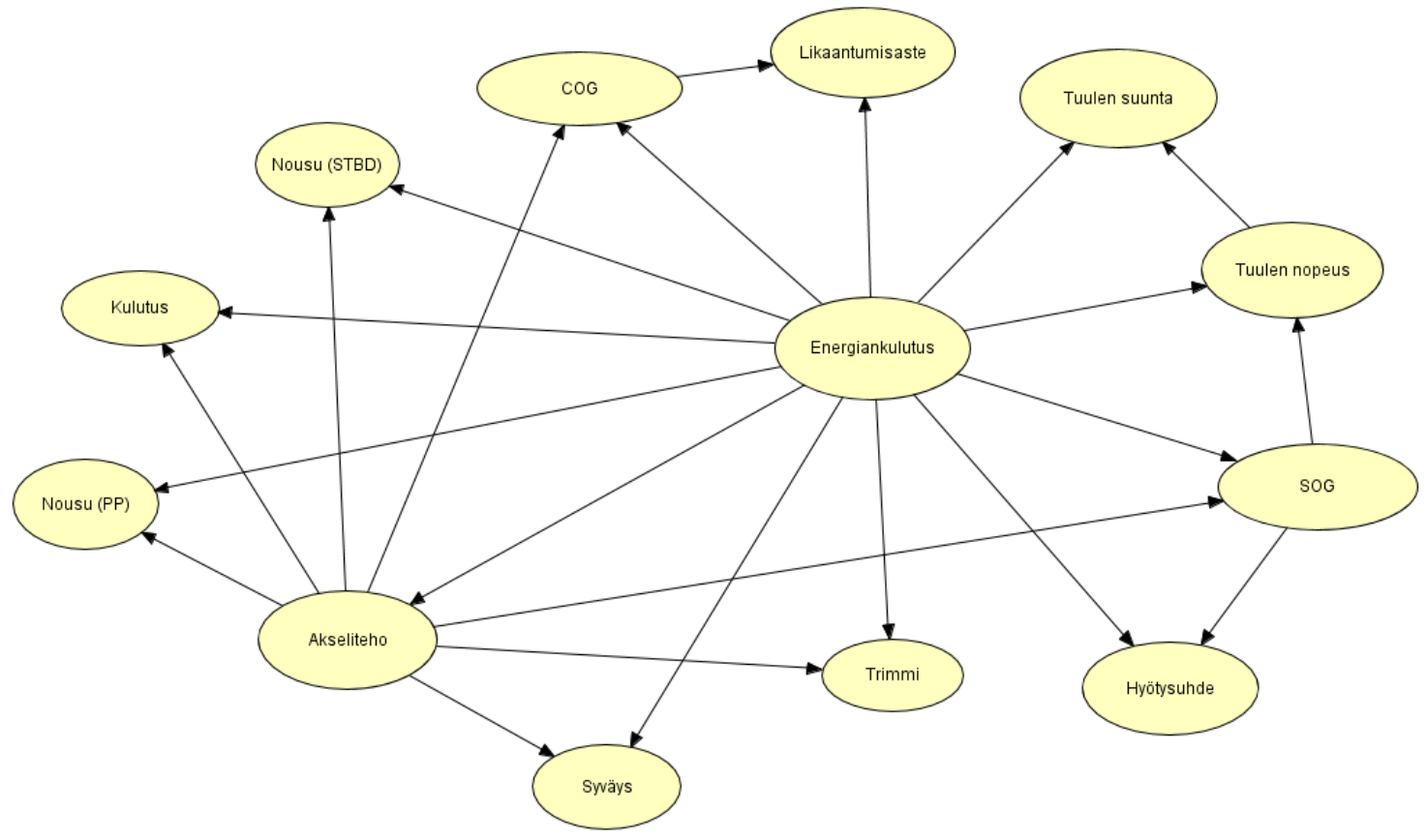

Kuva 18. Systeemin riippuvuussuhteet (tuuliolosuhteet mukana) 


\section{Tehodatan jakauma}

$(22,17 \ldots 22,25$ solmua $)$

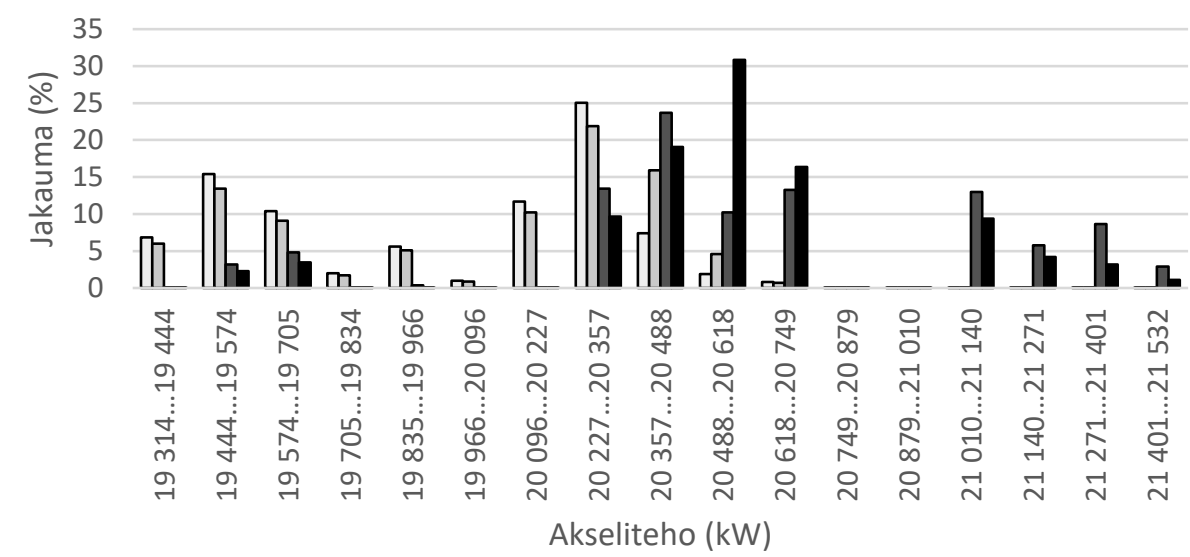

$\square$ Puhdas $\square$ Puhdas (tuulidata) aLikainen $\quad$ Likainen (tuulidata)

Kuva 19. Tehodatan jakauma nopeusluokassa $22,17 \ldots .22,25$ solmua

\section{Tehodatan jakauma \\ $(22,25 \ldots 22,33$ solmua $)$}

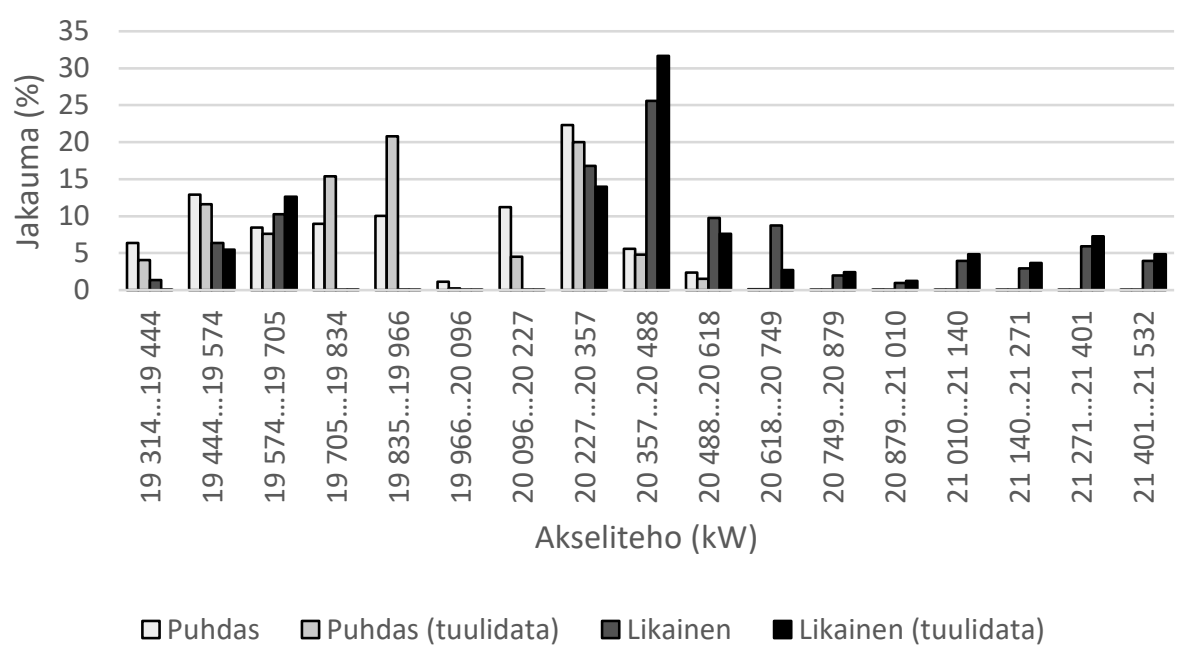

Kuva 20. Tehodatan jakauma nopeusluokassa 22,25...22,33 solmua 


\section{Tehodatan jakauma}

$(22,33 \ldots 22,41$ solmua $)$

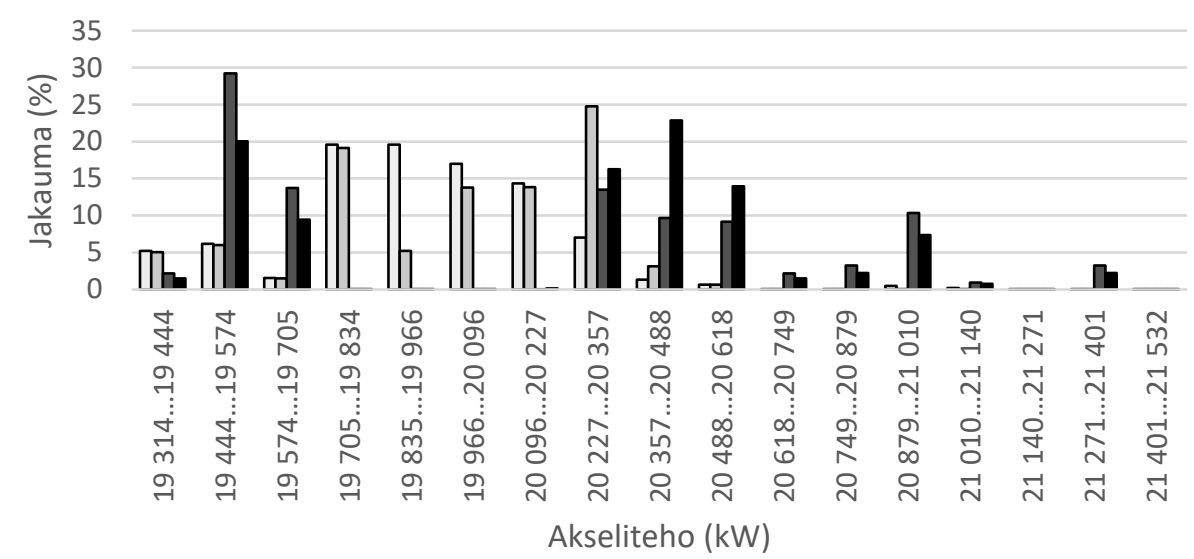

$\square$ Puhdas $\square$ Puhdas (tuulidata) $\square$ Likainen $\quad$ Likainen (tuulidata)

Kuva 21. Tehodatan jakauma nopeusluokassa 22,33...22,41 solmua

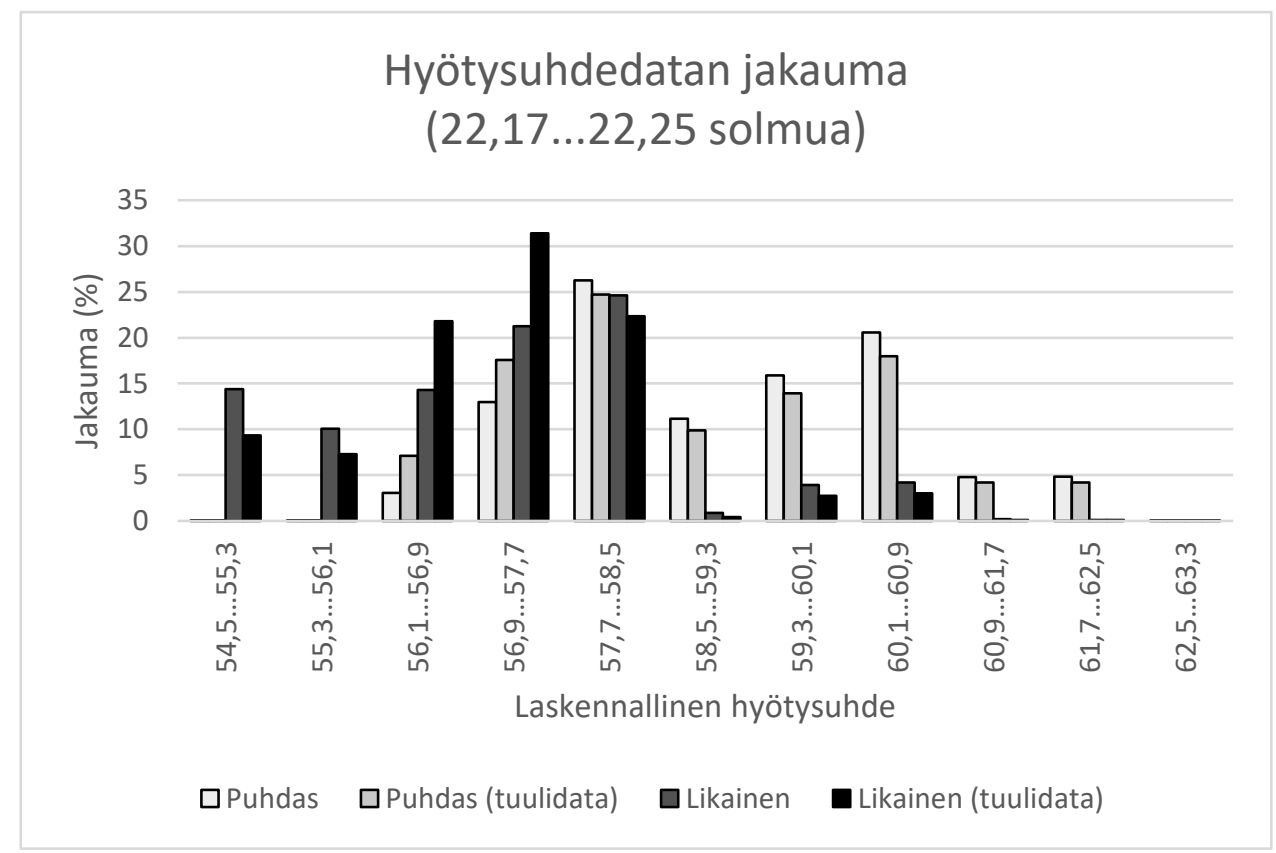

Kuva 22. Laskennallisen hyötysuhdedatan jakauma nopeusluokassa $22,17 \ldots 22,25$ solmua 


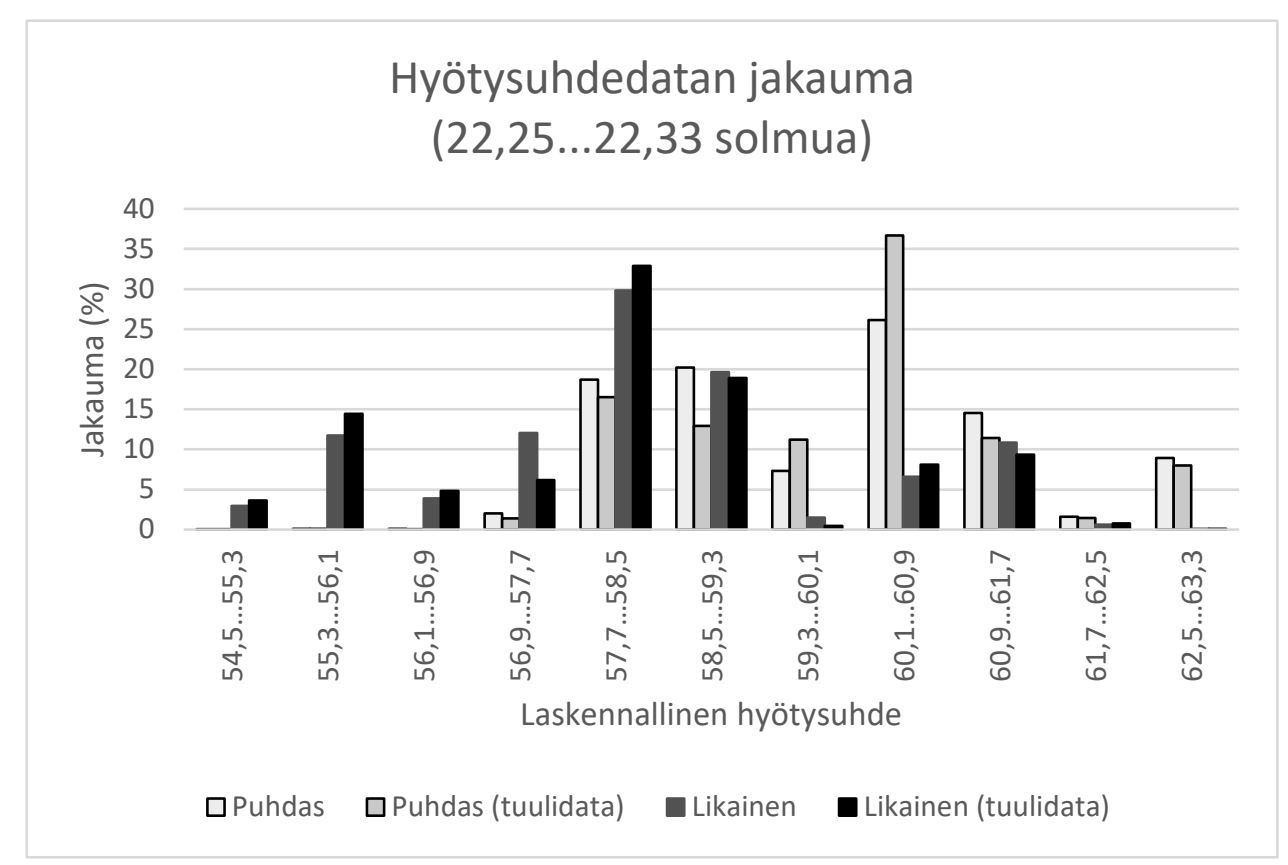

Kuva 23. Laskennallisen hyötysuhdedatan jakauma nopeusluokassa 22,25...22,33 solmua

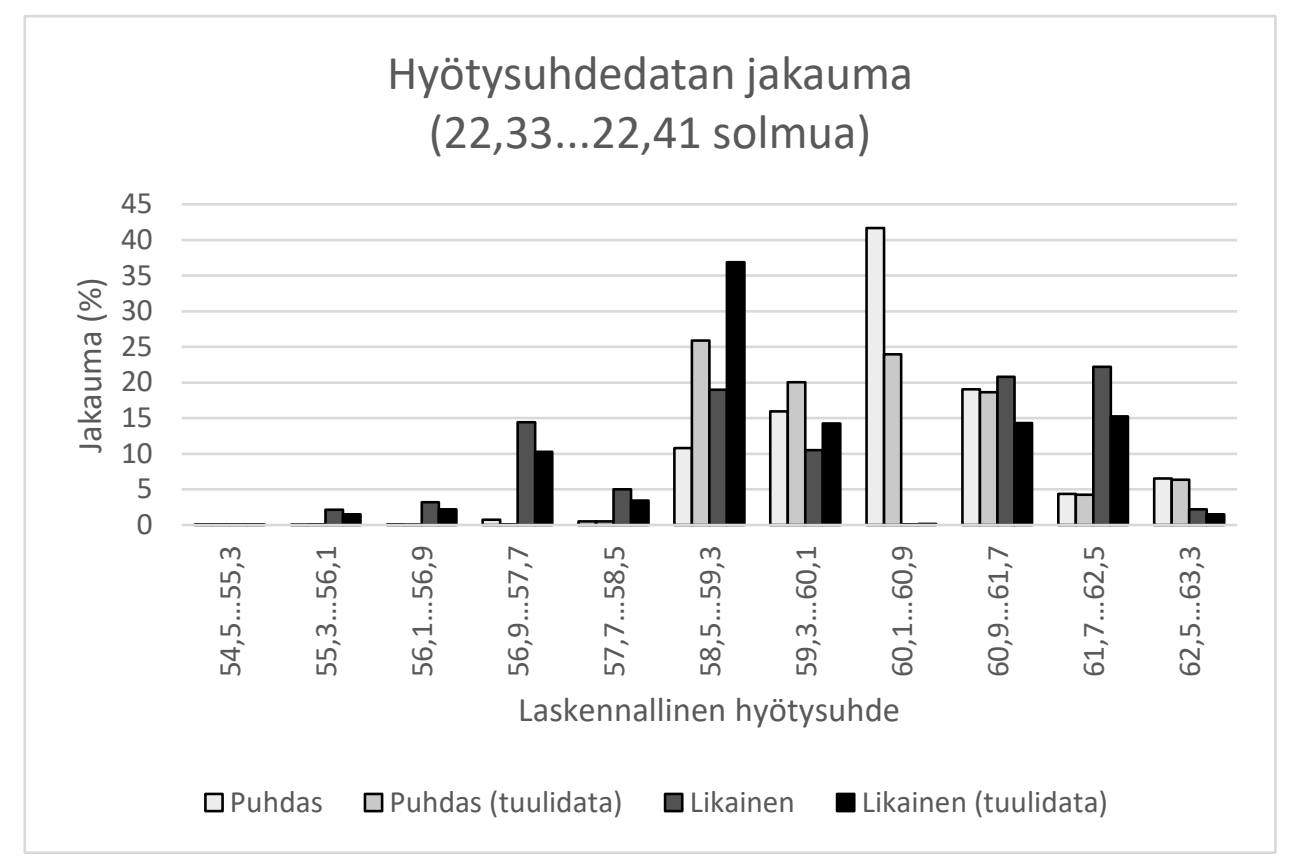

Kuva 24. Laskennallisen hyötysuhdedatan jakauma nopeusluokassa $22,33 \ldots 22,41$ solmua 


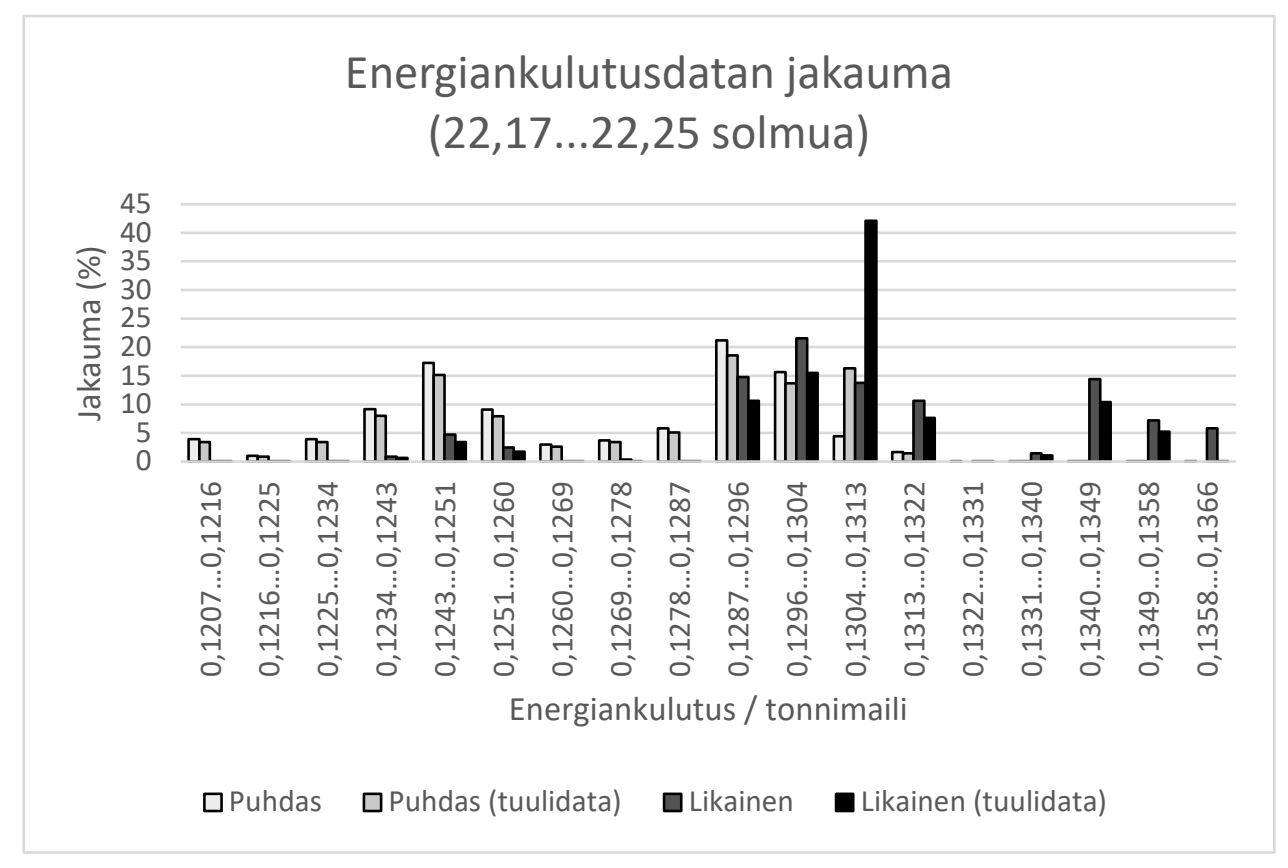

Kuva 25. Energiankulutusdatan jakauma nopeusluokassa 22,17...22,25 solmua

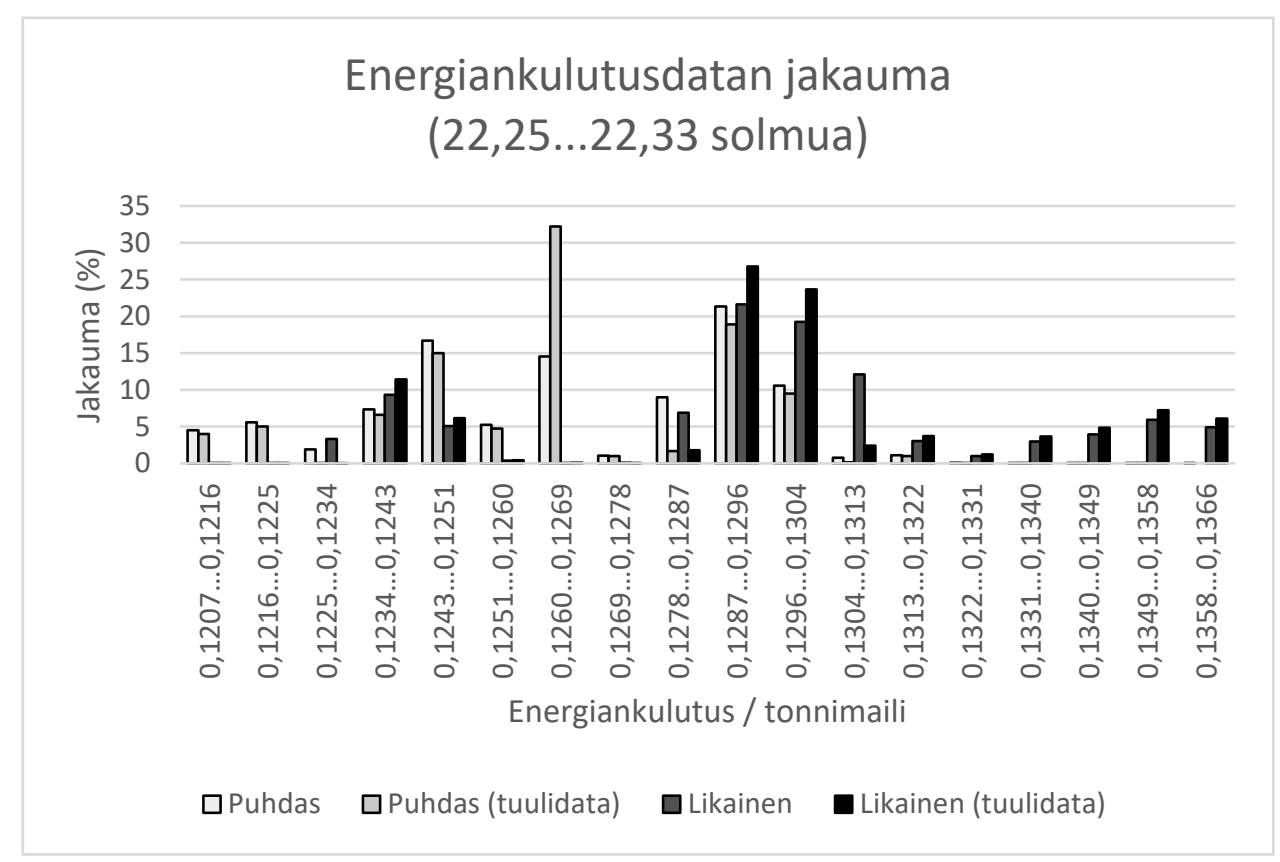

Kuva 26. Energiankulutusdatan jakauma nopeusluokassa 22,25...22,33 solmua 


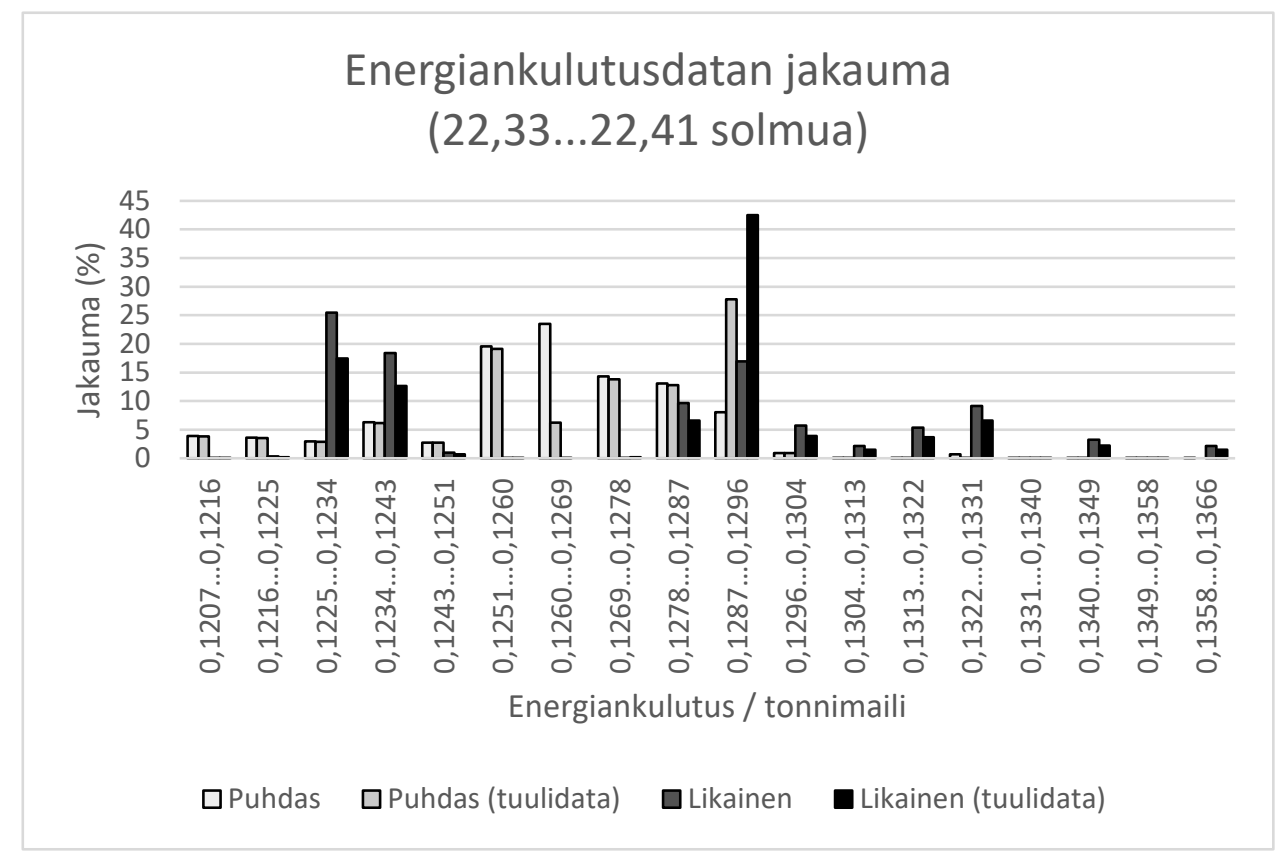

Kuva 27. Energiankulutusdatan jakauma nopeusluokassa 22,33...22,41 solmua

Taulukko 6. Odotusarvot puhtaalla ja likaisella pohjalla sekä niiden eroavuudet nopeusluokittain

\begin{tabular}{|c|c|c|c|c|c|c|c|c|c|}
\hline Datatyyppi & \multicolumn{9}{|c|}{ Nopeusluokka (solmua) } \\
\hline & \multicolumn{3}{|c|}{$22,17 \ldots 22,25$} & \multicolumn{3}{|c|}{$22,25 \ldots 22,33$} & \multicolumn{3}{|c|}{$22,33 \ldots 22,41$} \\
\hline $\begin{array}{l}\text { Pohjan } \\
\text { puhtaus }\end{array}$ & Puhd. & Lik. & $\begin{array}{l}\text { Ero } \\
(\%)\end{array}$ & Puhd. & Lik. & $\begin{array}{l}\text { Ero } \\
(\%)\end{array}$ & Puhd. & Lik. & $\begin{array}{l}\text { Ero } \\
(\%)\end{array}$ \\
\hline Akseliteho & 19822 & 20554 & 3,7 & 19818 & 20360 & 2,7 & 19818 & 20034 & 1,1 \\
\hline $\begin{array}{l}\text { Akseliteho } \\
\text { (tuulidata) }\end{array}$ & 19891 & 20510 & 3,1 & 19797 & 20382 & 3,0 & 19887 & 20138 & 1,3 \\
\hline $\begin{array}{c}\text { Lask. } \\
\text { hyötysuhde }\end{array}$ & 58,7 & 56,5 & $-3,7$ & 59,5 & 57,9 & $-2,8$ & 60,1 & 59,5 & $-1,1$ \\
\hline $\begin{array}{c}\text { Lask. } \\
\text { hyötysuhde } \\
\text { (tuulidata) }\end{array}$ & 58,5 & 56,7 & $-3,0$ & 59,7 & 57,8 & $-3,1$ & 59,9 & 59,2 & $-1,1$ \\
\hline $\begin{array}{c}\text { Energian- } \\
\text { kulutus }\end{array}$ & 0,1265 & 0,1305 & 3,2 & 0,1261 & 0,1292 & 2,5 & 0,1258 & 0,1268 & 0,8 \\
\hline $\begin{array}{c}\text { Energian- } \\
\text { kulutus } \\
\text { (tuulidata) }\end{array}$ & 0,1270 & 0,1303 & 2,6 & 0,1260 & 0,1295 & 2,7 & 0,1263 & 0,1274 & 0,9 \\
\hline
\end{tabular}

Taulukossa 6 on esitetty akselitehodatan, laskennallisen hyötysuhteen ja tonnimailikohtaisen energiankulutuksen odotusarvot ja niiden suhteellinen eroavuus nopeusluokittain. Tämän datan perusteella on havaittavissa suuruusluokaltaan muutaman prosentin eroavuus kaikissa näissä muuttujissa. Nopeusluokista suurin $(22,33 \ldots 22,41)$ näyttäisi 
poikkeavan kahdesta muusta nopeusluokasta, tosin tässäkin luokassa eroavuudet ovat vertailukelpoisia toisiinsa nähden.

\section{Johtopäätökset}

Tarkasteltaessa pohjan likaantumisen vaikutusta aluksen kulkuun laivaväen kokemukseen ja aiemmin tehtyihin tutkimuksiin perustuen, voidaan arvioida kulkuvastuksen kasvun olevan tässäkin tapauksessa kuukauden aikana suuruusluokaltaan muutaman prosentin. Tätä tukee myös nyrkkisääntö kulkuvastuksen kumulatiivisesta lisääntymisestä 0,125 \% vuorokautta kohden. Tällainen suuruusluokaltaan ehkä noin 2-6 \% muutos merkitsisi laskennallisesti siis 440-1320 kW lisätehoa likaisella pohjalla, mikäli valittu nopeus saavutettaisiin puhtaalla pohjalla $22000 \mathrm{~kW}$ akseliteholla. Koska kulkuvastuksen muutos on kumulatiivinen ja näin luonteeltaan selkeästi erilainen verrattuna esimerkiksi sääolosuhteiden aiheuttamaan muutokseen kulkuvastuksessa, on likaantuneen ja puhtaan pohjan välillä vallitseva eroavuus periaatteessa havaittavissa Naiivi Bayes -mallilla.

Verrattaessa 24.7 likaisella pohjalla tallentunutta dataa 28.-29.7. puhtaalla pohjalla tallentuneeseen dataan, havaitaan tuloksissa suuruusluokaltaan muutaman prosentin eroavuus (ks. taulukko 6). Kyseiset legit ovat keskenään hyvä vertailukohde, sillä aluksen lastaus on ollut sekä DWT:n että trimmin osalta hyvin samankaltainen. Molemmilla legeillä sääolosuhteet ovat olleet analyysille suotuisat ja tuulidataa sisältävään analyysiin on valittu ainoastaan tuulenvoimakkuudeltaan alle $2,34 \mathrm{~m} / \mathrm{s}$ vallinneissa olosuhteissa tallentuneet tiedot. Osa tästä eroavuudesta johtuu todennäköisesti pohjan likaantumiserosta. Toki on kuitenkin tärkeää noteerata, että merellä vallitsevat todelliset olosuhteet ovat vaikeasti todennettavissa ja mallinnettavissa, mutta tulokset antavat kuitenkin viitteitä siihen suuntaan, että pohjan likaantumisen vaikutus laivan kulkuvastukseen saattaa olla havainnoitavissa Naiivi Bayes -menetelmällä myös muutosten ollessa suhteellisen vähäisiä. Kuitenkin luotettavien tulosten varmistamiseksi analyysi on toistettava useilla vertailukelpoisilla legeillä. Yksittäisten, toisiaan seuraavien meripäivien välillä muutosta ei pysty havaitsemaan, mutta likaantuneen ja puhtaan pohjan välillä eroavuuden havaitsemiseen näyttäisi olevan hyvät mahdollisuudet.

Käytännössä asian todentamiseksi analysoitavasta datasta on valittava ajanjaksot, jolloin tuuli- ja virtausolosuhteet ovat analyysille suotuisat. Rannikkoasemien tuulidataa ja Itämerelle luotuja virtausmalleja voidaan ja kannattaakin hyödyntää, mutta laskennallisen hyötysuhteen käyrässä tapahtuvia muutoksia tarkastelemalla saadaan lisää varmuutta laivaa ympäröivien olosuhteiden vertailukelpoisuudesta. Aluksen lastauksen on myös oltava tarkastelujaksojen välillä mahdollisimman identtinen. DWT:n osalta on luotettava alukselta annettuun viralliseen ilmoitukseen. Aluksen trimmi vaikuttaa aluksen kulkuun sekä staattisena että dynaamisena muuttujana: Akselitehon kasvaessa keulatrimmi pyrkii kasvamaan ja muutoksen voimakkuuteen vaikuttaa lastaus. Toisaalta tällä laivalinjalla DWT:n matkakohtaiset muutokset ovat sangen kohtuullisia verrattuna esimerkiksi tankkereihin, mikä helpottaa huomattavasti tämän projektin tavoitteiden saavuttamista.

Artikkelisarjan seuraavassa osassa analysoidaan tallentunutta kulkudataa Naiivi Bayes -menetelmällä sisällyttäen analyysiin selkeästi pidempiä ajanjaksoja ennen ja jälkeen pohjan puhdistusajankohdan. Lisäksi datasta on valittava analyysiin sellaiset ajan- 
jaksot, jolloin meriolosuhteet ovat olleet rauhalliset ja aluksen lastitilanne mahdollisimman samankaltainen. Näillä lähtökohdilla luotettavien ja soveltamiskelpoisten tulosten saamista pohjan likaantumisen vaikutuksista aluksen kulkuun voidaan pitää mahdollisena.

\section{Kiitokset}

Kiitokset kaikille COMPLETE-hankkeen yhteistyötahoille. Tämän artikkelin valmistumista ovat edesauttaneet erityisesti seuraavat henkilöt ja tahot: Marko Piispa ja Mikko Nykänen (XAMK / KymiLabs); Justiina Halonen (XAMK / Merenkulun TKI); Miina Karjalainen (MeriKotka); Annukka Lehikoinen ja Inari Helle (Helsingin yliopisto); Anna-Liisa Perttilä, Michael von Pfaler, Timo Lamminen, Kim Söderholm, Ismo Jalonen, Pekka Silvennoinen, Tero Valtonen ja Ville Lehtomäki (Finnlines); Mika Rouhola ja Mauri Kalliomäki (DG Diving Group); Viron, Suomen ja Ruotsin ilmatieteen laitokset; Florent Nicolas, Marta Ruiz ja Manuel Sala-Perez (HELCOM); Annika Krutwa ja Katja Broeg (BSH); Dinis Oliveira ja Lena Granhag (CHALMERS-yliopisto); Susanna Airola, Sampo Haapalainen ja Patrick Borenius (Viking Line). Kiitokset myös kaikille muille tässä listassa mainitsemattomille henkilöille ja tahoille, jotka tunnistavat olleensa mukana COMPLETE-projektin Kaakkois-Suomen ammattikorkeakoulun vastuualueen työstämisessä.

\section{Viitteet}

[1] V. Masson-Delmotte, P. Zhai, H. O. Pörtner, D. Roberts, J. Skea, P.R. Shukla, A. Pirani, W. Moufouma-Okia, C. Péan, R. Pidcock, S. Connors, J. B. R. Matthews, Y. Chen, X. Zhou, M. I. Gomis, E. Lonnoy, T. Maycock, M. Tignor, T. Waterfield (eds.). Global Warming of $1.5^{\circ} \mathrm{C}$. An IPCC special report on the impacts of global warming of $1.5^{\circ} \mathrm{C}$ above pre-industrial levels and related global greenhouse gas emission pathways, in the context of strengthening the global response to the threat of climate change, sustainable development, and efforts to eradicate poverty. IPCC, 2018.

[2] H.-O. Pörtner, D.C. Roberts, V. Masson-Delmotte, P. Zhai, M. Tignor, E. Poloczanska, K. Mintenbeck, M. Nicolai, A. Okem, J. Petzold, B. Rama, N. Weyer. Summary for policymakers. In: IPCC Special Report on the Ocean and Cryosphere in a Changing Climate. IPCC, 2019.

[3] L. Laakso, S. Mikkonen, A. Drebs, A. Karjalainen, P. Pirinen, P. Alenius. 100 years of atmospheric and marine observations at the Finnish Utö Island in the Baltic Sea. Ocean science, 14:617-632, 2018. https://dx.doi.org/10.5194/os-14-617-2018

[4] H. Siegel, M. Gerth. Sea surface temperature in the Baltic Sea in 2018. HELCOM Baltic Sea environment fact sheet 2019, http://www.helcom.fi/baltic-sea-trends/environmentfact-sheets/hydrography/development-of-sea-surface-temperature-in-the-baltic-sea/, 2019.

[5] K. Kabel, M. Moros, C. Porsche, T. Neumann, F. Adolphi, T. Andersen, H. Siegel, M. Gerth, T. Leipe, E. Jansen, J.S.S. Damsté. Impact of climate change on the Baltic Sea ecosystem over the past 1000 years. Nature climate change, 2(12):871-874, 2012. https://doi.org/10.1038/nclimate1595

[6] B.R. MacKenzie, F.W. Köster. Fish production and climate: Sprat in the Baltic Sea. Ecology, 85(3):784-794, 2004. https://dx.doi.org/10.1890/02-0780 
[7] M. Lehtiniemi, H. Ojaveer, M. David, B.S. Galil, S. Gollasch, C. McKenzie, D. Minchin, A.Occhipinti-Ambrogi, S. Olenin, J. Pederson. Dose of truth - Monitoring marine non-indigenous species to serve legislative requirements. Marine policy, 54(1):26-35, 2015. https://dx.doi.org/10.1016/j.marpol.2014.12.015

[8] H. Ojaveer, B.S. Galil, J.T Carlton, H. Alleway, P. Goulletquer, M. Lehtiniemi, A. Marchini, W. Miller, A. Occhipinti-Ambrogi, M. Perharda, G.M Ruiz, S.L. Williams, A. Zaiko. Historical baselines in marine bioinvasions: Implications for policy and management. PLoS One, 13(8), e0202383, 2018. https://doi.org/10.1371/journal.pone.0202383

[9] D. Oliveira. The enemy below - Adhesion and friction of ship hull fouling. Chalmers university of technology, Gothenburg, 2017.

[10] S. Watanabe, N. Nagamatsu, K. Yokoo, Y. Kawakami. The augmentation in frictional resistance due to slime. Journal of Kansai society of naval architects, 131:45-53, 1969.

[11] G. Loeb, D. Laster, T. Gracik. The influence of microbial fouling films on hydrodynamic drag of rotating discs. In: J.D. Costlow, R. Tipper (editors), Marine biodeterioration: an interdisciplinary study. Naval Institute Press, Annapolis, 88-94, 1984.

[12] A. Lewkowicz, D. Das. Turbulent boundary layers on rough surfaces with and without a pliable overlayer: A simulation of marine fouling. International shipbuilding progress, 33:174-186, 1986. https://dx.doi.org/10.3233/ISP-1986-3338601

[13] D.K. Padilla, S.L. Williams. Beyond ballast water: Aquarium and ornamental trades as sources of invasive species in aquatic ecosystems. Frontiers in ecology and the environment, 2(3):131-138, 2004. https://doi.org/10.1890/1540-9295(2004)002[0131:BBWAAO]2.0.CO;2

[14] I.M. Gren, L. Isacs, M. Carlsson. Costs of alien invasive species in Sweden. AMBIO: A Journal of the human environment, 38(3):135-140, 2009. https://doi.org/10.1579/0044-7447-38.3.135

[15] K.Tsiamis, A. Zenetoss, I. Deriu, E. Gervasini, A.C. Cardoso. The native distribution range of the European marine non-indigenous species. Aquatic invasions, 13(2):187-198, 2018. https://doi.org/10.3391/ai.2018.13.2.01

[16] International maritime organization. International convention for the control and management of ships' ballast water and sediments. IMO, London, 2004.

[17] SopS 38/2017. Alusten painolastivesien ja sedimenttien valvontaa ja käsittelyä koskeva kansainvälinen yleissopimus, 2004.

[18] D. Minchin, S. Gollasch. Fouling and ships' hulls: How changing circumstances and spawning events may result in the spread of exotic species. Biofouling - the journal of bioadhesion and biofilm research, 19(1):111-122, 2003. https://doi.org/10.1080/0892701021000057891

[19] S. Gollasch, The importance of ship hull fouling as a vector of species introduction into the North Sea. Biofouling - the journal of bioadhesion and biofilm research, 18(2):105121, 2002. https://doi.org/10.1080/08927010290011361

[20] G.A. Hopkins, B.M. Forrest. Management options for vessel hull fouling: An overview of risks posed by in-water cleaning. ICES Journal of marine science, 65(5): 811-815, 2008. https://doi.org/10.1093/icesjms/fsn026

[21] I.C. Davidson, L.D. McCann, M.D. Sytsma, G.M. Ruiz. Interrupting a multi-species bioinvasion vector: The efficacy of in-water cleaning for removing biofouling on obsolete vessels. Marine pollution bulletin, 56(9):1538-1544, 2008. https://doi.org/10.1016/j.marpolbul.2008.05.024

[22] Completing management options in the Baltic Sea Region to reduce risk of invasive species introduction by shipping. http://www.balticcomplete.com [Viitattu 6.11.2019] 
[23] J.P. Monty, E. Dogan, R. Hanson, A.J. Scardino, B. Ganapathisubramani, N. Hutchins. An assessment of the ship drag penalty arising from light calcareous tubeworm fouling. Biofouling, 32(4):451-464, 2016. https://doi.org/10.1080/08927014.2016.1148140

[24] M.P. Schultz, J.A. Bendick, E.R. Holm, W.M. Hertel. Economic impact of biofouling on a naval surface ship. Biofouling, 27(1):87-98, 2011. https://doi.org/10.1080/08927014.2010.542809

[25] M.P. Schultz, G. Swain. The effect of biofilms on turbulent boundary layers. Journal of fluids engineering, 121:44-51, 1999. https://doi.org/10.1115/1.2822009

[26] P. Borenius. Viking Line Ltd., suullinen tiedonanto, 24.9.2019.

[27] M. Rouhola. DG Divers Group oy, suullinen tiedonanto, 17.10.2019.

[28] BIMCO. Hull fouling clause for time charter parties (updated 16 July 2015), special circular no 3, 2013. https:www.bimco.org/contracts-and-clauses/bimco-clauses

[29] International maritime organization. International convention on the control of harmful anti-fouling systems on ships. IMO, London, 2001.

[30] International maritime organization. Guidelines for the control and management of ships' biofouling to minimize the transfer of invasive aquatic species. Resolution marine environment protection committee, 207(62), IMO, London, 2011.

[31] M. Hilbert. Big data for development: A review of promises and challenges. Development policy review, 34(1):135-174, 2016. https://doi.org/10.1111/dpr.12142

[32] M. Hilbert, P. López. The world's technological capacity to store, communicate and compute information. Science, 332(6025):60-65, 2011. https://doi.org/10.1126/science. 1200970

[33] Y.K. Demirel, O. Turan, A. Incecik. Predicting the effect of biofouling on ship resistance using CFD. Applied ocean research, 62:100-118, 2017. https://doi.org/10.1016/j.apor.2016.12.003

[34] M.P. Schultz, K.A. Flack. The rough-wall turbulent boundary layer from the hydraulically smooth to the fully rough regime. Journal of fluid mechanics, 580:381-405, 2007. https://doi.org/10.1017/S0022112007005502

[35] M. Leer-Andersen, L. Larsson. An experimental/numerical approach for evaluating skin friction on full-scale ships with surface roughness. Journal of marine science and technology, 8:26-36, 2003. https://doi.org/10.1007/s10773-003-0150-y

[36] O. Turan, Y.K. Demirel, S. Day, T. Tezdogan. Experimental determination of added hydrodynamic resistance caused by marine biofouling on ships. $6^{\text {th }}$ European transport research conference proceedings, 14:1649-1658, 2016

[37] J. Woodward. Making things happen: A theory of causal explanation, Oxford University Press, 2003

[38] J. Pearl. Miksi? Syyn ja seurauksen uusi tiede. Terra Cognita, 2018.

[39] P. Myllymäki, H. Tirri. Bayes-verkkojen mahdollisuudet. Teknologian kehittämiskeskus, Teknologiakatsaus 58/98, 1998.

[40] E.V. Lewis (ed.). Principles of naval architecture. Volume II: Resistance, propulsion and vibration. The society of naval architects and marine engineers, New Jersey, 1988.

[41] E. Tupper. Introduction to naval architecture. Butterworth-Heinemann, Oxford, 1996.

[42] A.F. Molland, S.R. Turnock, D.A. Hudson. Ship resistance and propulsion. Practical estimation of ship propulsive power. Cambridge university press, Cambridge, 2011.

[43] A.M. Kracht. Design of bulbous bows. The transactions of the society of naval architects and marine engineers collection, 78:197-217, 1978.

[44] M.P. Schultz. Frictional resistance of antifouling coating systems. Journal of fluids engineering, 126:1039-1047, 2004. https://doi.org/10.1115/1.1845552

[45] F.R. Brady, I.L. Singer. Mechanical factors favoring release from fouling release coatings. Biofouling, 15(1-3):73-81, 2000. https://doi.org/10.1080/08927010009386299 
[46] T.M. Mitchell. Machine learning. McGraw-Hill, 1997.

[47] D. Hand, H. Mannila, P. Smyth. Principles of data mining. The MIT Press, 2001.

[48] P. Domingos, M. Pazzani. On the optimality of the simple Bayesian classifier under zeroone loss. Machine learning, 29(2-3):103-130, 1997. https://doi.org/10.1023/A:1007413511361

[49] E. Mäkinen (toim.). Tietojenkäsittelytieteellisiä tutkielmia. Tampereen yliopisto: Informaatiotieteiden yksikön raportteja 36/2015, 2015.

[50] A. Stuart, K. Ord. Kendall's advanced theory of statistics: Volume 1 -distribution theory. Edward Arnold publishers, 1994.

[51] C. K. Chow, C. N. Liu. Approximating Discrete Probability Distributions with Dependence Trees. IEEE transactions on information theory, IT-14(3):462-467, 1968. https://doi.org/10.1109/TIT.1968.1054142

[52] N. Friedman, D. Geiger, M. Goldszmidt. Bayesian network classifiers. Machine learning, 29(2-3):131-163, 1997. https://doi.org/10.1023/A:1007465528199

[53] E. Altarriba. Laivojen pohjien likaantumisen vaikutus kulkuvastukseen Itämerellä: teoreettinen viitekehys ja empiiriset mittaukset. Rakenteiden mekaniikka, 53(3):209-238, 2020. https://doi.org/10.23998/rm.79336

[54] C.W.B. Grigson. An accurate smooth friction line for use in performance prediction. Transactions of the royal institution of naval architects, 135:149-162, 1993.

[55] C.W.B. Grigson, A planar friction algorithm and its use in analyzing hull resistance. Transactions of the royal institution of naval architects, 142:76-115, 2000.

[56] S.A. Harvald. Resistance and propulsion of ships. John Wiley \& Sons, New York, 1983.

[57] H.E. Guldhammer, S.A Harvald. Ship resistance - Effect of form and principal dimensions. Akademisk forlag, Copenhagen, 1974.

[58] H.O. Kristensen, M. Lützen. Prediction of resistance and propulsion power of ships. Technical university of Denmark, project no 2010-56, WP2, report no. 4, 2013.

[59] H.O. Kristensen, H. Psaraftis. Prediction of resistance and propulsion power of Ro-Ro ships. Technical university of Denmark, project no 2014-122, WP2.3, report no. 1, 2016.

[60] S. L. Lauritzen. The EM algorithm for graphical association models with missing data. Computational statistics \& data analysis, 19:191-201, 1995. https://doi.org/10.1016/01679473(93)E0056-A

[61] R. G. Cowell \& A. P. Dawid. Fast retraction of evidence in a probabilistic expert system. Statistics and computing, 2:37-40, 1992. https://doi.org/10.1007/BF01890547

Elias Altarriba

Kaakkois-Suomen ammattikorkeakoulu

Pääskysentie 1, 48220 Kotka

elias.altarriba@xamk.fi 